\title{
Review Article \\ Estrogen Signaling and the Aging Brain: Context-Dependent Considerations for Postmenopausal Hormone Therapy
}

\author{
Natasha N. Mott and Toni R. Pak \\ Department of Cell and Molecular Physiology, Loyola University Chicago Stritch School of Medicine, 2160 S First Avenue, \\ Maywood, IL 60153, USA \\ Correspondence should be addressed to Toni R. Pak; tpak@lumc.edu
}

Received 12 April 2013; Accepted 21 May 2013

Academic Editors: F. Escobar-Jimenez, H. Galbo, E. Hajduch, M. Hiriart, H.-Q. Qu, and H. Ueshiba

Copyright (C) 2013 N. N. Mott and T. R. Pak. This is an open access article distributed under the Creative Commons Attribution License, which permits unrestricted use, distribution, and reproduction in any medium, provided the original work is properly cited.

\begin{abstract}
Recent clinical studies have spurred rigorous debate about the benefits of hormone therapy (HT) for postmenopausal women. Controversy first emerged based on a sharp increase in the risk of cardiovascular disease in participants of the Women's Health Initiative (WHI) studies, suggesting that decades of empirical research in animal models was not necessarily applicable to humans. However, a reexamination of the data from the WHI studies suggests that the timing of HT might be a critical factor and that advanced age and/or length of estrogen deprivation might alter the body's ability to respond to estrogens. Dichotomous estrogenic effects are mediated primarily by the actions of two high-affinity estrogen receptors alpha and beta (ER $\alpha$ \& ER $\beta$ ). The expression of the ERs can be overlapping or distinct, dependent upon brain region, sex, age, and exposure to hormone, and, during the time of menopause, there may be changes in receptor expression profiles, post-translational modifications, and protein:protein interactions that could lead to a completely different environment for $\mathrm{E}_{2}$ to exert its effects. In this review, factors affecting estrogen-signaling processes will be discussed with particular attention paid to the expression and transcriptional actions of ER $\beta$ in brain regions that regulate cognition and affect.
\end{abstract}

\section{Introduction}

According to the CDC (2008), the average lifespan for women in the USA is $\sim 81$ years of age. While the average lifespan has been steadily increasing over the past century ( $\sim 8$ years in 1900), the average age at which reproductive senescence, menopause, occurs has remained relatively constant between $45-55$ years of age $[1,2]$. Including the prepubescent years, this leaves women living about half of their lives without high levels of circulating ovarian hormones. The two primary ovarian hormones are $17 \beta$-estradiol $\left(\mathrm{E}_{2}\right)$ and progesterone, both of which are required for female reproduction. Many positive anecdotal experiences are reported during times in the reproductive cycle when $E_{2}$ is high, sparking further investigation into the role of $\mathrm{E}_{2}$ in various nonreproductive processes, including those pertaining to cognition and mood. The vast majority of basic science studies have described positive effects of $E_{2}$ on cognitive processes at a molecular level, and, importantly, older postmenopausal females exhibit significant deficits when performing tasks that require the use of working memory, attentional processing, and executive function [3-8]. The natural aging process is coincident with menopause, which confounds studies attempting to differentiate between the molecular mechanisms specific to menopause versus aging. Therefore, studies examining the physiological and molecular functions of estrogen receptors during periods of estrogen deprivation with respect to natural aging are requisite to understanding how reintroducing estrogens in aged postmenopausal women will affect neurological processes. In spite of the wealth of studies investigating the effects of HT on relevant health concerns, there are still very few conclusive arguments for or against HT to ameliorate neurological issues. Moreover, it is very likely that the actions of estrogens regulate opposing processes depending upon brain region and genetic composition of neurons involved, creating complex issues regarding the lack of specificity of $\mathrm{E}_{2}$ treatment. Nevertheless, some insight into general functions of $E_{2}$ in the brain can be gleaned from existing data that 
demonstrate that (1) there is a critical window of time surrounding menopause for which HT can be beneficial, suggesting that aging is an important factor, (2) progestins are not likely to be beneficial for cognitive and affective neurological issues, and (3) the type of estrogen used may be crucial. Given these important conclusions, this review will focus on the molecular mechanisms of $\mathrm{E}_{2}$ signaling in the brain and how variables that might contribute to these signaling patterns can be altered by age.

\section{The Menopausal Transition: $E_{2}$ Decline and Health Concerns}

Menopause is defined by the Mayo Clinic as "the permanent end of menstruation and fertility, occurring 12 months after your last menstrual period." Menopause is marked by a reduced oocyte number attributable to progressive atresia of ovarian follicles and by declining circulating levels of $E_{2}$ and progestins. The perimenopausal transition is typically 48 years, during which most women experience symptoms including hot flushes, night sweats, mood swings, sleep disturbances, vaginal dryness and atrophy, as well as urinary incontinence, most of which are alleviated by hormone $\left(\mathrm{E}_{2}\right)$ replacement therapy (HT/ET). Until recently, a great deal of evidence suggested that estrogens have positive effects on cognition, neuroprotection, memory, anxiety, depression, as well as bone and cardiovascular health [5, 9-13].

The paramount studies to present negative consequences of HT were the Women's Health Initiative (WHI) and the ancillary studies including the Women's Health Initiative Study on Cognitive Aging (WHISCA) and the Women's Health Initiative Memory Study (WHIMS). Data from these studies showed that a combination therapy of conjugated equine estrogen/medroxyprogesterone acetate (CEE/MPA) increased risk for mild cognitive impairment and decreased global cognitive functioning, but CEE alone did not have any significant effect on cognitive functioning [14-16]. Poststudy analyses have revealed many confounding factors in the WHI studies ranging from the choice of a reference group to the age of participants and the choice of ET used (CEE) $[4,17,18]$, as well as the use of MPA, which has been shown to have adverse effects on memory after one dose in adulthood [19]. While the WHI studies showed negative or neutral effects of estrogen therapy, many other basic science and observational studies have shown just the opposite. The Kronos Early Estrogen Prevention Study (KEEPS) recently announced findings that suggested that $\mathrm{E}_{2}$ therapy had a positive effect on mood and memory. Participants receiving CEE showed significant improvement in symptoms of depression, anxiety, and a trend toward reduced feelings of anger/hostility. Importantly, CEE treatment or Premarin (Wyeth-Ayerst, Philadelphia, PA, USA) is a mixture of several estrogenic compounds, but primarily estrone sulfate and ring B unsaturated estrogens such as equilin and equilenin, which can differentially activate $\mathrm{ER}$ isoforms as compared to $\mathrm{E}_{2}$ alone [20]. Participants receiving CEE self-reported a trend toward better recall of printed materials as compared to placebo, and women using transdermal $\mathrm{E}_{2}$ tended to report fewer memory-related complaints. Another study performed a meta-analysis of 36 randomized HT clinical trials (RCT) focusing on cognition [21]. The length of treatment, type of memory, variety of hormone, and age of the participant were all variables that drastically altered the outcomes of each trial. Results from the meta-analysis indicated that verbal memory was most often affected by HT, and younger women tended to have a better outcome in this category. There was also a trend toward worse outcomes on memory tests in patients treated with CEE treatment alone compared to those treated with biologically identical $\mathrm{E}_{2}$. Moreover, treatment with estrogens alone (i.e., absent cotreatment with progestins) was overall associated with positive results on memory tests. In conclusion, data from these clinical trials have revealed the importance of using bioidentical hormones for HT and that downstream signaling processes for memory and mood can be affected by the choice of estrogen and/or combination of hormones used as therapeutics.

\section{Estrogen Receptor Signaling}

Estrogen signaling is mediated primarily through two receptors $(\mathrm{ER} \alpha$ and $\mathrm{ER} \beta)$. ERs are class I members of the nuclear hormone superfamily of receptors, deemed as a ligand-inducible transcription factors [22]. Classically, ERs were thought to be localized in the cytoplasm bound to intracellular chaperone proteins until induced by ligand to translocate to the nucleus, according to the two-step hypothesis coined by Jensen et al. [23]. Following ligand binding, ERs undergo a conformational change that allows for dimerization, translocation to the nucleus, and DNA binding or association with other transcription factors to regulate gene transcription; however, we now know that ER signaling is much more complex.

For example, ERs are involved in other "nongenomic" molecular functions including RNA processing, secondmessenger signaling cascades, and rapid dendritic spine formation in neurons. Of particular importance in the brain, the discovery of rapid signaling processes implicates $E_{2}$ as a neuromodulator; however, local synthesis of $E_{2}$ has been the subject of fervent debate. While it is likely that there is de novo synthesis of $\mathrm{E}_{2}$ within the parenchyma, due to technical challenges, the exact levels and changes with age and circulating hormones have yet to be identified $[24,25]$. It is also difficult to determine how local $\mathrm{E}_{2}$ may affect ER action. Most reports suggest an implicit role for local $E_{2}$ at the synapse and membrane [26], but whether nuclear/genomic activities of ERs are affected has yet to be established. Recent data from our laboratory demonstrate that $\mathrm{E}_{2}$ can alter miRNA-expression [27], and from others have shown that $\mathrm{ER} \alpha$ can associate with miRNA processing enzymes such as Drosha [28]. Data from our laboratory (unpublished observations) and others have shown that ERs are involved in alternative splicing processes, and one study has demonstrated direct interaction of phosphorylated ER $\alpha$ with splicing factor (SF) 3a p120 that potentiates alternative splicing through EGF/ $\mathrm{E}_{2}$ crosstalk [29]. These relatively novel ER functions may be explained by examining well-studied 
components of classic NR signaling such as the structural properties of the receptors.

\section{Structural Contributions to ER Activity}

Class I nuclear receptors (NRs) including ER $\alpha$ and ER $\beta$ have a characteristic structure comprised of five functional domains labeled A-E, and a sixth domain (F) unique to ERs (Figure 1). The A/B domain contains an activator function-1(AF-1-) like domain that allows for associations with coregulatory proteins and other transcription factors. Notably, the $\mathrm{A} / \mathrm{B}$ domain is the least conserved domain between ER $\alpha$ and $\operatorname{ER} \beta$ ( $17 \%$ homology), and it may be responsible for the observed ligand-independent actions of $\operatorname{ER} \beta$ [30]. The C domain, is a DNA-binding domain that allows the receptor to bind a specific DNA sequence called an Estrogen Response Element (ERE) to regulate transcription of genes containing this sequence within their promoter region. Two zinc fingers forming a helix-loop-helix structure allow for appropriate spacing (3 nucleotides) between an inverted hexameric palindromic repeat that is described as the canonical ERE. The exact nucleotide sequence of hormone response elements can vary and in part, dictate the affinity an NR has to regulate a particular gene [31]. The D domain is a hinge-like region that allows the receptor to undergo a conformational change once activated and also contains a nuclear localization sequence. The best-studied region of ERs is the $\mathrm{E}$ domain, also referred to as the ligand-binding domain (LBD). Characterization using X-ray crystallography has shown that the LBD consists of 12 ordered alpha-helices that are essential for conferring ligand specificity [32]. The orientation of helix 12 is critical to the conformation NRs adopt once bound to a particular type of ligand, and ultimately influence the ability of the receptor to bind other proteins and activate gene transcription. Helix 12 contains the core residues of the activator function-2 (AF2) domain, a short amphipathic conserved alpha-helix that interacts with coregulatory proteins through an LxxLL motif. Adjacent to the AF-2/E domain is the less characterized $\mathrm{F}$ domain that is unique to ERs. ER $\alpha$ has a larger $\mathrm{F}$ domain than $\operatorname{ER} \beta$, and the two receptors only share about $18 \%$ homology within this region. ER $\alpha$ dimerization and interactions with coregulators are altered when the $\mathrm{F}$ domain is deleted or modified, demonstrating that the $\mathrm{F}$ domain is a relevant structure for $\mathrm{ER} \alpha$ transcriptional regulation, but a clear role for this domain for $E R \beta$ has yet to be determined $[33,34]$. Importantly, naturally occurring human ER $\beta$ splice variants have altered $\mathrm{E}$ and $\mathrm{F}$ domains, which can affect hormone responsiveness in tissues that express these variants.

While the overall sequence homology between $\mathrm{ER} \alpha$ and $\mathrm{ER} \beta$ is greater than $60 \%$, the specific gene targets of each receptor appear to be vastly different. For example, a variety of cancer cell models have identified an antiapoptotic, proliferative role for $\mathrm{ER} \alpha$, whereas $\mathrm{ER} \beta$ tends to promote apoptosis and regulate antiproliferative genes [35-38]. It is well known that $\mathrm{ER} \alpha$ and $\mathrm{ER} \beta$ are readily able to form heterodimers when expressed in the same cell, adding another layer of complexity to the regulation of estrogen responsive genes. $\mathrm{ER} \alpha$ and $\mathrm{ER} \beta$ both bind EREs, but the affinity for one receptor

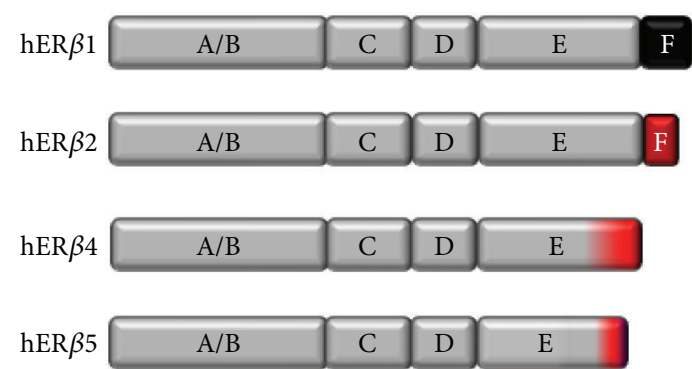

(a)

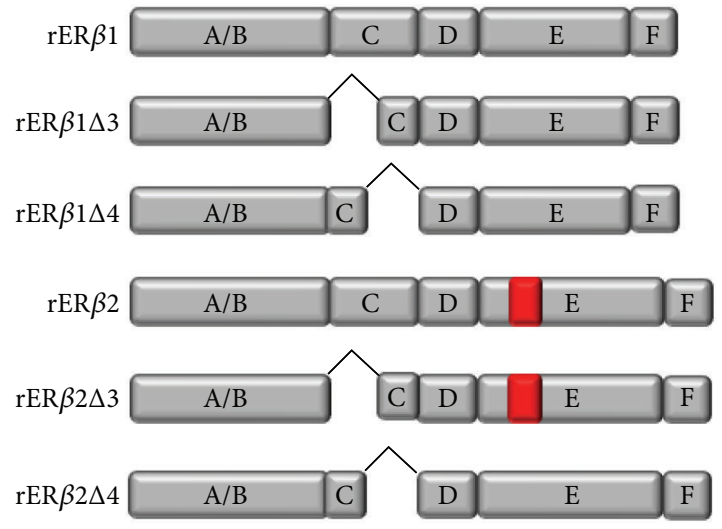

(b)

FIGURE 1: Representative image of domains within human and rat $\mathrm{ER} \beta$ splice variants. Human $\mathrm{ER} \beta$ splice variants (a) contain truncations and changes in amino acid sequence in the C-terminus $\mathrm{E}$ and $\mathrm{F}$ domains. Rat ER $\beta$ splice variants (b) contain an 18-aminoacid insert in the LBD/E domain and/or exon 3/4 exclusions in the DNA-binding domain.

or the other can depend highly on the specificity of the DNA sequence being regulated and the ligands present [39-41]. Therefore, it is important to consider the overlap in ER $\alpha$ and ER $\beta$ preferred transcriptional response elements when both receptors are expressed in the same system.

\section{Expression of ERs in the Brain: A Complex Story}

The principal determinant of $\mathrm{E}_{2}$ action is the expression of $\operatorname{ER} \alpha, \operatorname{ER} \beta$, their alternatively spliced variants, or some combination of each, which is cell-type specific even within distinct brain nuclei. ER expression has been studied extensively, yet there are few definitive statements that can be made about the regulation of ER $\beta$ expression. It can be noted that ER expression profiles can vary throughout the life-span, in particular when there are dramatic changes in circulating hormone levels, such as puberty and menopause (Figure 2). Not only can ER expression vary dependent upon sex, age, and $\mathrm{E}_{2}$ treatment, but these factors can also direct subcellular localization, which ultimately dictates ER functions. Accordingly, contextual studies that map the exact cellular expression patterns of each receptor and their splice 


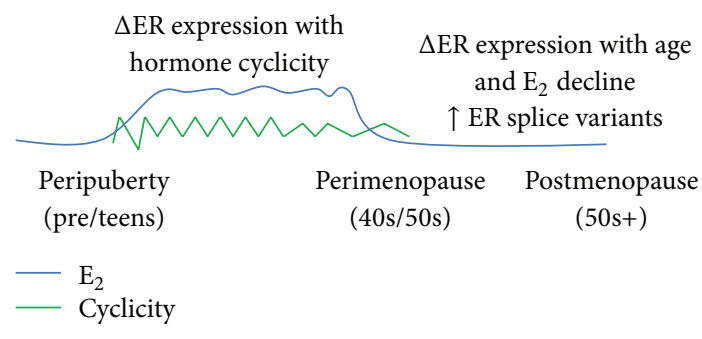

FIGURE 2: Timeline showing factors affecting ER gene expression throughout the female life-span. Brain ER gene expression patterns are altered with age, sex, and exposure to circulating hormone. Circulating hormones fluctuate with age, most dramatically at the time of puberty and menopause therefore contributing to changes in ER gene expression. Additionally, alternative splicing increases with age, thus potentially diversifying the ER gene expression profile.

variants are a critical first step in creating a comprehensive examination of $E_{2}$-regulated processes in any system.

The female vertebrate reproductive organs tend to be dominated by the expression of $\operatorname{ER} \alpha$, whereas $\operatorname{ER} \beta$ is expressed largely in nonreproductive tissues. $\operatorname{ER} \beta$ was first cloned from prostate tissue [42], and it has since been shown to have the highest levels of expression in the central nervous system and cardiovascular tissue, as well as lung, kidney, colorectal tissue, mammary tissue, and the immune system [43]. Consequently, some of the most prominent phenotypic problems observed in mice lacking a functional ESR2 gene ( $\beta \mathrm{ERKO}$ mice) are neurological deficits. By contrast, ER $\alpha$ knockout mice have no gross brain-related phenotypes, but they exhibit decreased $\mathrm{E}_{2}$-mediated neuroprotection following an ischemic event [44]. Overall, the phenotypes observed in $\mathrm{ER} \alpha$ - and $\mathrm{ER} \beta$-null mouse models suggest that $\mathrm{ER} \beta$ is potentially more important for mediating nonreproductive $\mathrm{E}_{2}$-governed processes than ER $\alpha$.

$\mathrm{ER} \alpha$ and $\mathrm{ER} \beta$ are coexpressed in some regions of the hypothalamus, such as the medial amygdala (MeA), the bed nucleus of the stria terminalis (BNST), and the periaqueductal grey area. However, ER $\alpha$ is predominant in hypothalamic nuclei that control reproduction, sexual behavior, and appetite (e.g., arcuate (ARC), medial preoptic (MPoA), and ventromedial (VM)) but $\mathrm{ER} \beta$ is the predominant isoform in the nonreproductive associated nuclei (e.g., paraventricular (PVN), supraoptic (SON), and suprachiasmatic (SCN)) as well as the hippocampus, dorsal raphe nuclei, cortex, and cerebellum $[45,46]$. In the hippocampus, mRNA and protein for both ERs have been detected and are well established as mediating both genomic and nongenomic processes [47-49]. Nuclear and extranuclear ER $\beta$ mRNA and immunoreactivity (IR) have been detected in principal cells as well as in many other nuclei of cells within the ventral CA2/3 [46, 47]. Although not as prevalent as $\operatorname{ER} \beta, \operatorname{ER} \alpha$ has also been detected in the hippocampus, primarily within GABAergic interneurons $[47,49]$.

ER expression is also often found to be sexually dimorphic. As one would expect, many regions of the hypothalamus exhibit a great deal of sexual dimorphism due in part to differences in sexual behavior and regulation of gonadotrophic hormones, but regions such as the BNST also display some sex-related differences in ER expression. For example, ER $\alpha$ in the BNST can be induced in somatostatin-positive neurons of male, but not female, rats [50]. ERs have also been shown to be sexually dimorphic in the developing rodent hippocampus, but not in adults $[51,52]$. However one report identified $\mathrm{ER} \beta \mathrm{mRNA}$ in the adult female, but not male, rhesus macaque basal ganglia and hippocampus [53]. Importantly, a lack sexually dimorphic regional ER expression does not preclude differential responses to estrogens, as other effector molecules can alter estrogen-responsive processes.

Expression of ERs can vary not only with chromosomal sex, but also in response to the hormonal milieu. For instance, it is well accepted that $\mathrm{ER} \alpha$ expression is autoregulated by $\mathrm{E}_{2}$, primarily through proteasomal degradation, [54] but also perhaps on a transcriptional level by $\mathrm{E}_{2}$-bound $\operatorname{ER} \beta$ [55]. The $\mathrm{ER} \beta$ gene (ESR2) promoter region has not been extensively characterized, but it has been shown to contain $\mathrm{E}_{2}$-responsive cis sequence-binding sites for Oct-1 and Sp-1, which interact with ERs via trans factors suggesting a molecular mechanism for $\mathrm{E}_{2}$-mediated autoregulation of its receptor. There is also an Alu repeat sequence that may contain an ERE that could act as an ER-dependent enhancer [56]. Conversely, in vitro and in vivo studies investigating the effects of $\mathrm{E}_{2}$ on $\mathrm{ER} \beta$ expression have yielded inconsistent conclusions depending upon cell type, animal species, and age. For instance, in the T47D human breast cancer cell line, $\mathrm{E}_{2}$ upregulated $\mathrm{ER} \beta$ [57]. However, ER $\beta$ expression was decreased by $E_{2}$ in mammary glands of lactating mice that coexpress ER $\alpha$ [58]. ER $\beta$ was also decreased in the PVN of rats subjected to OVX $+\mathrm{E}_{2}$ [59]. Thus, it appears that $\mathrm{E}_{2}$ may regulate $\mathrm{ER} \alpha$ and $\mathrm{ER} \beta$; however, this effect is highly dependent upon cell type, and possibly upon the coexpression of other ERs.

In addition to sex and $\mathrm{E}_{2}$, aging also appears to influence ER expression. Overall, decreased nuclear $\mathrm{E}_{2}$ binding has been reported in the hypothalamus and anterior pituitary of aged female rats compared to young ones, but the change in $\mathrm{E}_{2}$ binding was not necessarily attributed to a decrease in total ER expression $[60,61]$, suggesting a shift in the ratio of ERs and/or subcellular localization. While overall nuclear $\mathrm{E}_{2}$ binding within the hypothalamus may decrease with age, changes to ER expression patterns with age remain contentious. In general, it appears that age alone does not eliminate $\mathrm{ER} \alpha$ expression in the brain, but regional specificity and $E_{2}$ availability may be important factors $[62,63]$, and an increase in ESR promoter methylation has been correlated with age in other systems $[64,65]$. One study reported varied middle age-specific reduction in hypothalamic ER with $\mathrm{E}_{2}$ treatment [66], yet another study showed that $\mathrm{E}_{2}$ decreased hypothalamic ER expression significantly in all ages tested (3, 11, and 20 months) [67]. Specific to ER $\alpha$, a work by Chakraborty and colleagues determined that immunoreactive cell numbers did not always change following OVX and $\mathrm{E}_{2}$ replacement. Rather, their study revealed that with advanced age (24-26 months compared to 3-4 and 10-12 months) the number of ER $\alpha$-positive cells was increased or it stayed the same in different hypothalamic nuclei [68]. In the hippocampus, $\mathrm{ER} \alpha$ was decreased after long-term estrogen deprivation (LTED, 10 weeks), regardless of $\mathrm{E}_{2}$ replacement 
following LTED, but $\mathrm{E}_{2}$ deprivation had no effect on $\mathrm{ER} \beta$ [11]. The same report demonstrated decreased levels of ER $\beta$ in very old rats (24-month females compared to 3-month diestrus females). In general, most reports suggest that aging decreases ER $\beta$ expression, but, like ER $\alpha$, this effect may be highly region specific. An age-related decrease in ER $\beta$ expression in the brain is underscored by a corresponding increase in $\mathrm{CpG}$ methylation of the ESR2 promoter in middle-aged (912 months) rats [69]. Other reports describe decreases in ER $\beta$ protein and message in some areas but not in others $[63,70]$. Taken together, there are a number of reports attempting to identify the parameters that control ER expression such as age, sex, and response to $E_{2}$; however, with such vast deviations in expression with cell type there is still much to be learned about expression of these receptors, especially in brain regions controlling nonreproductive behaviors.

\section{Alternative Splice Variants}

Based upon the highly variable reports that differ in sex and age of animals as well as exposure to hormone, it may be possible that these studies are unknowingly detecting changes in splice variant expression, which could change $\mathrm{E}_{2}$ responsiveness as well as downstream gene regulation. Not only can ERs heterodimerize to regulate gene transcription, but there are a number of alternatively spliced variants of each receptor that are endogenously expressed and that potentially contribute to the diverse tissue-specific actions of $E_{2}$. Alternative splicing of ERs alters inherent signaling properties of the receptor including ligand, and DNA-binding affinities, nuclear localization, and dimerization, depending on where the alternative splice site is encoded. A number of ER splice variant transcripts and other proteins have been identified in demented human brains, breast, and prostate, and, in some reports, an increase in alternative splicing is correlated with pathology [71-75]. Also interesting, age alone may increase alternative splicing of some gene products [76]. The identified ER $\beta$ human splice variants are truncated at the Cterminus of the receptor (Figure 1(a)); however, we provided experimental evidence that the $\mathrm{C}$-terminus of the receptor is not required for $\mathrm{ER} \beta$-mediated transcription, especially with regard to the identified human splice variants [77]. Unlike the human splice variants, rodent $\operatorname{ER} \beta$ splice variants identified to date have been shown to have either an exon inclusion in the ligand-binding domain, creating (rER $\beta 2$ ), or an exon deletion in the DNA-binding domain $\operatorname{rER} \beta 1 \Delta 3$ or $\operatorname{rER} \beta 1 \Delta 4$ or both $\operatorname{rER} \beta 2 \Delta 3$ and $\operatorname{rER} \beta 2 \Delta 4$ (Figure 1(b)) $[37,78,79]$. Exon inclusion (rER $\beta 2$ variants) has been shown to produce a protein that binds $\mathrm{E}_{2}$ with a 35 -fold decrease in affinity. In contrast, ERs with exon 3 and 4 deletions are unable to bind DNA, but they can still mediate transcription through protein:protein interactions with other transcription factors such as AP-1, and it can bind $\mathrm{E}_{2}$ as well as $\mathrm{rER} \beta 1$ $[37,80]$. Importantly, the transcriptional functions of $\mathrm{rER} \beta 1$ are significantly altered when coexpressed with other splice variants, likely due to a weaker interaction with coactivator proteins $[81,82]$. Despite lower $\mathrm{E}_{2}$ binding and/or lack of DNA binding, the rodent and human splice variants retain a constitutive ligand-independent transcriptional function, at both basic and complex promoters [77, 83, 84], suggesting that these splice variants have an important endogenous biological function. Indeed, unliganded ER $\beta 1$ or apo-ER $\beta 1$ has been reported to regulate a subset of genes distinct from those regulated by ER $\beta 1$ when bound to $\mathrm{E}_{2}$ [41]. Conversely, the human splice variants do not bind ligand with great affinity [85], and they might therefore only regulate the class of genes that unliganded ER $\beta$ targets.

The downstream target genes of ER $\beta$ splice variants might be an important consideration at the time of menopause, as ER expression profiles and alternative splicing tend to change with age [76]. One recent report demonstrated an increase in ER $\beta 2$ expression in the hippocampus of 9month old, middle-aged rats following short-term (6 days) $\mathrm{E}_{2}$ deprivation that was significantly decreased compared to the Sham group after $\mathrm{E}_{2}$ administration [86]. Importantly, $E_{2}$ replacement no longer affected $E R \beta 2$ expression in the hippocampus after LTED (180 days). That study also reported a decrease in hippocampal neurogenesis and increased floating behavior in a forced swim test, thus functionally correlating increased ER $\beta 2$ with mood regulation and potentially cognition. Thus, the expression and functions of $\operatorname{ER} \beta$ splice variants are absolutely critical to understand the effects of estrogen particularly at times of sustained $\mathrm{E}_{2}$ deprivation with regard to cognition and affect. While ER $\beta 2$ expression has been assessed in the young male rat brain [87], and other variants have been described in some brain regions $[80,88]$, there is a general lack of data on most ER $\beta$ splice variants, especially in aged female brains.

Some of the splice variants identified to date have been characterized as dominant negative receptors, serving to inhibit activation of the full-length receptor [89]; however, most identified variants do not bind ligand with the same affinity and have the potential to differentially regulate target genes. While several splice variants for ER $\beta$ have been identified in many model systems including mouse [90], rat [45, 46], and monkey [91], there is a general lack of comparative studies on expression and functionality of human $\mathrm{ER} \beta$ variants, especially in neuronal systems. Furthermore, changing expression levels of one or more alternatively spliced variants during a period of $\mathrm{E}_{2}$ deprivation may drastically change general receptivity and downstream functions of $\mathrm{E}_{2}$.

\section{Novel Protein:Protein Interactions for $\mathbf{E}_{2}$-Mediated Nuclear Processes}

Protein:protein interactions are an essential relay in the regulation of dynamic cellular processes. Immediately following translation, ERs typically associate with a chaperone protein to ensure proper folding, protect from degradation, and assist the ER in becoming poised to accept ligand. Once bound to ligand, ERs can dimerize and act as transcription factors to mediate gene regulation or associate with membrane proteins to initiate a signaling cascade. When acting as transcription factors, ERs associate with a number of coregulatory proteins that assist in activating or repressing $\mathrm{E}_{2}$-regulated genes. Coregulatory interactions are more characterized for ER $\alpha$ 
than $\operatorname{ER} \beta$, and, importantly, less clear is how $\operatorname{ER} \beta$ mediates ligand-independent transcription. In addition to the wellestablished ER interaction partners, many novel interacting proteins have not yet been characterized and could be critical for nuclear processes not limited to gene transcription.

\section{HSPs and Chaperone Proteins}

According to the classical two-step hypothesis, inactive nuclear receptors are constantly accompanied and protected from degradation by a number of chaperone proteins, typically members of the heat-shock protein (HSP) family. This receptor:chaperone complex has been studied extensively, and while the idea of a protective role for chaperones is well supported, this complex can also perform other functions. For instance, HSP:ER complexes can serve to preactivate a hormone receptor by forcing a conformational change in ER such that it is able to bind its cognate hormone. The initial HSP complex consists of the ER, HSP70, and HSP70-interacting protein ( $\mathrm{HiP})$, as well as other accessory and scaffolding proteins [92]. HSP90 is recruited to the complex, and HSP70 dissociates, creating the mature HSP:ER complex [93]. HSP90 induces a conformational change in the nuclear receptor, and the ER is released from the complex, ready to dimerize and bind DNA or other transcription factors to regulate gene transcription. However, some studies suggest that HSPs could have a broader role than originally thought. For example, in Drosophila, HSPs are required for DNA binding, and in some instances they may regulate $\mathrm{NR}$ action [94]. Interestingly, aging and $\mathrm{E}_{2}$ can alter HSP70 in a cell-type specific manner [95-98]. However, recent data from our lab (Table 1) demonstrated that HSP70 more readily associates with ER $\beta$ in aged female hippocampus following $\mathrm{E}_{2}$ treatment compared to the young ones in which HSP70:ER $\beta$ association decreased following $E_{2}$ treatment. We also observed no significant changes in HSP70 or ER $\beta$ expression, suggesting that changes in the HSP70:ER $\beta$ interaction with age in response to $E_{2}$ change are a result of $E_{2}$ responsiveness and/or activation of $\mathrm{ER} \beta$.

\section{Transcriptional Proteins and ERs}

The process of transcribing DNA into RNA is a systematic process that involves multiprotein complexes binding to DNA, modifying histone marks, and initiating RNA synthesis. $\mathrm{ER} \alpha$, but not $\mathrm{ER} \beta$, has been shown to directly interact with TFIIB, IIE, IIF, and TIID proteins that initiate transcription $[99,100]$. However, experimental evidence from coimmunoprecipitation studies has demonstrated interactions between $\operatorname{ER} \beta$ coregulatory proteins as well as other transcription factors. Coregulatory proteins are transcriptional accessory proteins that enhance or repress transcription of target genes. In general, coactivators enhance gene transcription, whereas corepressors block it. However, recent data suggest that seemingly nontranscriptional proteins may have context-dependent coregulatory functions. Importantly, certain coregulators can also be governed by age and $\mathrm{E}_{2}[101-$ 103]; thus, recent discoveries imply that ER-mediated gene regulation is not as well understood as previously thought.

The best studied and well-established group of coregulatory proteins that selectively associate with NRs is the steroid receptor coactivator (SRC/p160) family. The SRC family is composed of three members, SRC-1, SRC-2, and SRC-3, all of which contain canonical LxxLL motifs known as the nuclear receptor (NR) box. This motif interacts with AF2 domains in ER $\beta$, as well as other NR family members such as glucocorticoid receptor (GR), progesterone receptor (PR), thyroid hormone receptor (TR), and ER $\alpha$ [104]. SRC members have intrinsic histone acetyltransferase activity (HAT, DNA activating) and interact with CREB-binding protein (CBP) [105]. CBP/p300 proteins are also coactivators that have intrinsic HAT activity and can recruit ASC-2 and other known coregulatory proteins [106]. Confirmed coregulatory interaction partners for several NRs that do not belong to the SRC family include estrogen-receptorassociation protein (ERAP 140) [107], nuclear corepressor (NCoR) [108] silencing mediator of retinoic acid and thyroid hormone receptor (SMRT) [109], and many others. As is the case with our understanding of $\operatorname{ER} \beta$ interactions with basic transcriptional machinery, studies investigating ER $\beta$ :coregulator interactions are sparse, which may be due to uniquely challenging issues associated with $\operatorname{ER} \beta$, such as a lack of high-fidelity biochemical tools, complicated structural properties, and, or pleiotropic physiological actions that are specific to $\mathrm{ER} \beta$.

In 2010, Anna Ma lovannaya and colleagues directed a high-throughput study (not including ER $\beta$ ) aiming at compiling a database for the endogenous coregulator pool "nuclear receptor complexome" [110]. In this study, a number of novel protein interactions were identified, and studies such as these are identifying proteins as "coregulators" that had been previously thought to serve completely different functions. One group of relatively novel coregulatory proteins are the E3 ubiquitin-protein ligases such as E6-associated proteins (E6-AP) [111]. While these proteins were thought to serve primarily as ubiquitin-conjugating enzymes, they have recently been highlighted as transcriptional enhancers of NRmediated activity independent of ligase function. Similarly, a group of E3-ligases that conjugate small ubiquitin like modifier (SUMO) proteins to a target protein called PIAS are also now considered NR coregulators and they utilize a typical LxxLL motif. In one study, a decrease in ER expression following LTED or with advanced age coincided with an increase in ER association with an E3-ubiquitin ligase, CHIP [11]. Together, these newly described roles for HSPs and E3 ligases raise novel questions about estrogen signaling, such as when is an E3-ligase:ER complex targeted for transcriptional regulation versus degradation? Also, when are HSPs merely performing a chaperone/protective function versus directing transcriptional processes? Future efforts aiming at elucidating the complexity of age-related changes in receptor structure and recruitment of coregulatory proteins could provide important insight into these seemingly paradoxical findings. 
TABLE 1: Protein interactions with ER $\beta$ were altered by age and $E_{2}$. Selected proteins that were significantly altered $(P<0.05)$ in their association with ER $\beta$ depending on age and $E_{2}$ treatment. Experimental paradigm: young ( 3 month) and aged (18 month) female Fischer 344 rats were ovariectomized and hormone deprived for 7 days. Following deprivation, animals were administered $2.5 \mu \mathrm{g} / \mathrm{kg} E_{2}$ (plasma levels $=$ $79.45 \pm 22.5 \mathrm{pg} / \mathrm{mL}$ ) or vehicle (safflower oil) via subcutaneous injection once/day for 3 days. Nuclear protein was isolated from the ventral hippocampus and coimmunoprecipitated for $\mathrm{ER} \beta$ (a beam 14C8) and associated proteins. Protein interactions were identified and quantified using 2D-DIGE/DeCyder and ESI MS/MS. YV = young + vehicle; $\mathrm{YE}=$ young $+E_{2} ; \mathrm{AV}=$ aged + vehicle; $\mathrm{AE}=\operatorname{aged}+E_{2}$.

\begin{tabular}{|c|c|c|c|c|c|c|c|c|c|c|}
\hline \multirow[b]{2}{*}{ Accession no. } & \multirow{2}{*}{$\begin{array}{l}\text { Molecular } \\
\text { weight } \\
(\mathrm{Kda})\end{array}$} & \multirow{2}{*}{$\begin{array}{l}\text { Estimated } \\
\text { isoelectric } \\
\text { point }\end{array}$} & \multirow{2}{*}{$\begin{array}{l}\text { PEAKS } \\
\text { score }\end{array}$} & \multirow[b]{2}{*}{ \% Coverage } & \multirow[b]{2}{*}{ ID } & \multicolumn{4}{|c|}{ Interaction with $\mathrm{ER} \beta$} & \multirow[b]{2}{*}{ Function } \\
\hline & & & & & & $\begin{array}{c}\text { Young } \\
\text { vehicle }\end{array}$ & $\begin{array}{c}\text { Young } \\
E_{2}\end{array}$ & $\begin{array}{c}\text { Aged } \\
\text { vehicle }\end{array}$ & $\begin{array}{c}\text { Aged } \\
E_{2}\end{array}$ & \\
\hline gi| 149038929 & 80 & 5.75 & 49.4 & 6.43 & Gelsolin & - & $\uparrow$ & - & - & $\begin{array}{c}\text { Actin- } \\
\text { binding } \\
\text { coactivator }\end{array}$ \\
\hline gi| 116242507 & 75 & 5.97 & 93 & 14.58 & $\begin{array}{c}\text { Heat-shock protein } \\
70\end{array}$ & - & $\downarrow$ & - & $\uparrow$ & Chaperone \\
\hline gi| 120538378 & 47 & 5.7 & 93.2 & 10.72 & $\begin{array}{c}\text { Heterogeneous } \\
\text { nuclear } \\
\text { ribonucleoprotein } \\
\text { H1/2 }\end{array}$ & - & $\uparrow$ & - & - & RNA splicing \\
\hline
\end{tabular}

\section{Nuclear Actin: Setting the Stage}

Coregulatory interactions may be poised upon a bed of nuclear actin, which has recently been identified as a dynamic molecular stage for which many nuclear processes are performed such as transcription, chromatin remodeling, mRNA processing, and nuclear import/export. The general events that initiate transcription are well established; however, the process by which all of the molecular components are temporally layered into a complex is still unclear. Nuclear actin is essential in forming the preinitiation complex on a promoter, elongation, and RNP organization, as well as remodeling of chromatin [112-114], and, as mentioned previously, ERs are also key factors in these processes. In one study, ER $\alpha$ and $\beta$-actin were coimmunoprecipitated on the $\mathrm{E}_{2}$ responsive pS2/TFF1 promoter, indicating that ER and nuclear actin may work in concert to regulate transcriptional processes under control of estrogens [115]. The interaction between ERs and actin is not yet fully investigated, but data from our lab (unpublished observations) and others [116] imply that both $\mathrm{ER} \alpha$ and $\mathrm{ER} \beta$ may utilize nuclear actin to perform various functions. Another actin-binding, protein gelsolin, caps actin filament ends, and it has been shown to be an NR coactivator [117, 118]. Gelsolin may assist in actin polymerization, allowing transcriptional machinery to be brought in proximity of target genes; however, it remains unclear how gelsolin enhances AR/ER transcriptional activity. Data from our lab indicate that gelsolin:ER $\beta$ interactions increase with $\mathrm{E}_{2}$ treatment in young but not aged animals (Table 1). Gelsolin has been shown to increase with age [119], but a lack of significant interaction with ER $\beta$ despite increased expression of gelsolin could again suggest an alteration in $\mathrm{ER} \beta$ function with age.

Actin is also commonly associated with ubiquitous multifunctional RNA-binding proteins such as heterologous nuclear riboproteins (hnRNPs), which also associate with ERs [120]. hnRNPs associate within the matrix of nuclear actin, accompany transcripts out of the nucleus, participate in alternative splicing, and can modulate transcription [121].
Phosphorylated hnRNPK has been shown to mediate translation of specific mRNAs [122], and hnRNPH is involved in splicing and mRNA polyadenylation $[123,124]$. In the past, the association of NRs with hnRNPs was thought to be nonspecific due to the ubiquitous nature of these proteins, but recent studies are no longer ruling out an important interaction between NRs and hnRNPs that may assist in transcription and/or splicing $[125,126]$. Data from our lab and others demonstrate a dynamic interaction between both $\mathrm{ER} \alpha$ and ER $\beta$ and hnRNPs (Table 1), and, furthermore, data, demonstrated that $\mathrm{E}_{2}$ might regulate expression of members of the hnRNP family [127]. As noted previously, age-related increases in splicing could lead to aberrant signaling, not only for $\mathrm{E}_{2}$-mediated processes, but also for cellular processes in general.

Nuclear ER interaction partners have historically been a distinct class of nuclear receptor coregulators that seemed to solely assist ERs in gene transcription; however, the number of interaction partners for ERs is increasing. Further investigation into $\mathrm{ER} \beta$-associated proteins is required, as far as NRs are concerned; data specific to ER $\beta$ are inadequate to make broad conclusions. Moreover, post-translational modifications to coregulatory proteins, ERs or changes in their expression patterns due to age or sustained estrogen deprivation could all contribute to an altered microenvironment, setting the stage for atypical estrogen signaling upon therapeutic reinstatement of hormones (Figure 3).

\section{Estrogens and Cognition}

Most empirical and observational data give merit to the idea that estrogens have a positive effect on cognitive processes, increased spine densities [128, 129], enhanced synaptic plasticity [130-132], and improved memory [133, 134]; however, the particular receptor(s) and the mechanisms that regulate these processes remain unclear. There are a myriad of behavioral studies suggesting that $\mathrm{E}_{2}$ enhances prefrontal cortex (PFC) and hippocampal-dependent tasks. 


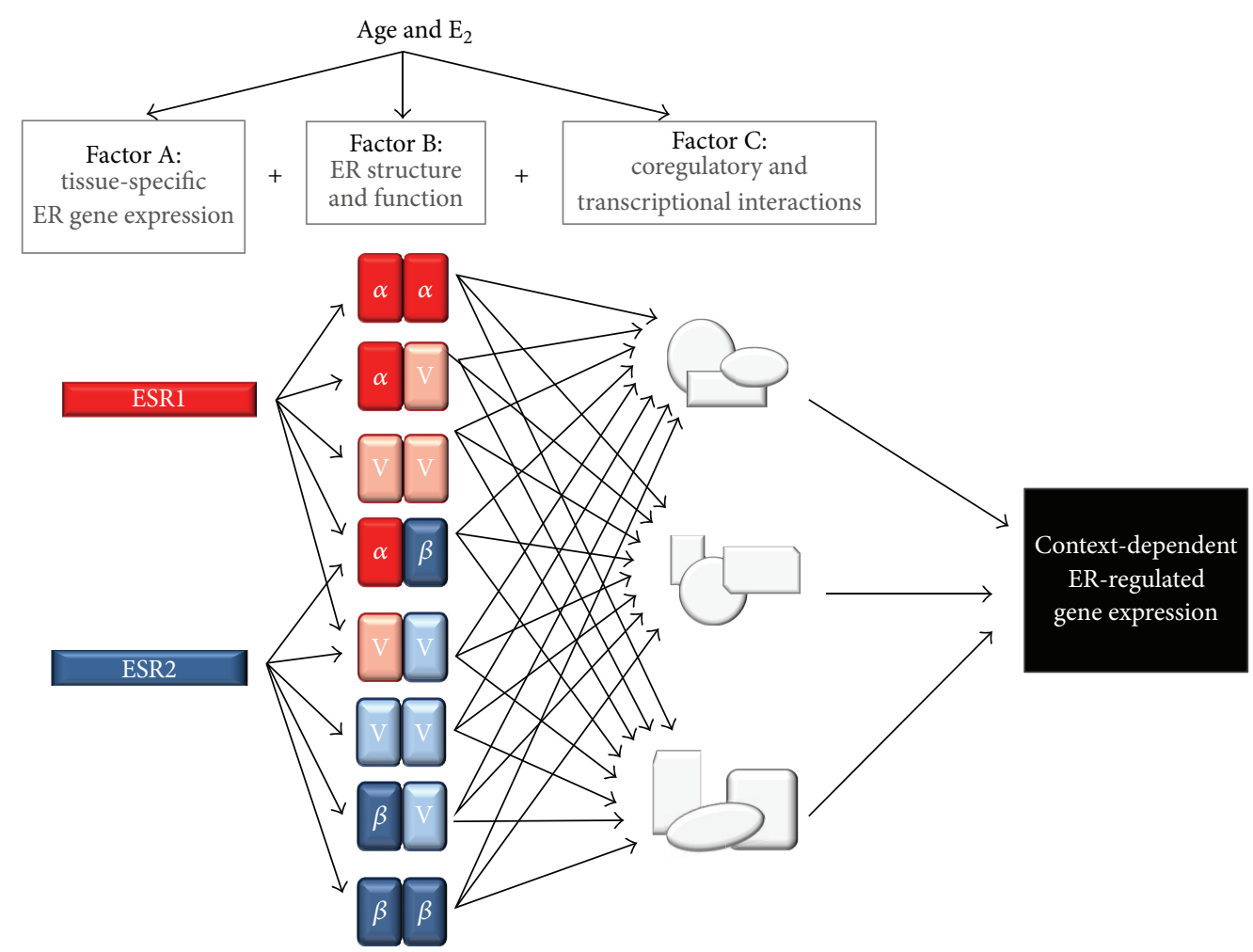

FIGURE 3: Age and hormonal milieu exponentially increase the potential diversity of estrogen receptor signaling leading to context-dependent gene regulation. Age and $\mathrm{E}_{2}$ influence $\mathrm{ER}$ gene expression, alternative splicing, coregulatory protein expression, and interaction, which ultimately direct ER-target gene transcription.

For example, long-term $\mathrm{E}_{2}$ deprivation diminished aged female rhesus macaques' performance in a delayed response task, a PFC- dependent task [135]. $\mathrm{E}_{2}$ also enhanced object recognition under a number of different paradigms [136138], and there are also multiple lines of evidence supporting $\mathrm{E}_{2}$-mediated neuroprotection which may be important for cognition, especially after stroke [139-142].

Pharmacological targeting of the receptors with ER selective ligands has been a standard method for investigating the behavioral, physiological, and cellular actions of $\mathrm{E}_{2}$ mediated distinctly through $\mathrm{ER} \alpha$ and/or ER $\beta$; however, valuable insight has also come from the $\mathrm{ER} \beta$-null $(\beta \mathrm{ERKO})$ mice. $\beta \mathrm{ERKO}$ mice have significantly fewer neurons in the cortex, hypothalamus, amygdala, and ventral tegmental area compared to WT. They also exhibit neuronal shrinkage and hyperproliferation of glia by 3 months of age, as well as having high levels of apoE and apoE-dependent deposition of amyloid plaques throughout the CNS by 12 months of age [143]. These mice also demonstrate spatial learning deficits in the Morris water maze [144] and a decrease in hippocampal- and amygdaladependent memory in a fear-conditioning paradigm that is accompanied by decreased synaptic plasticity in hippocampal slice preparations [145]. The critical role of ER $\beta$ in higherlevel brain functions has been deduced from these studies and others, warranting a full investigation of the wide-spread molecular actions of $\mathrm{E}_{2}$ known to contribute to cellular processes on at least two levels: at the synapse and on the genome.
Long-term potentiation (LTP) is an important component of learning and memory. It represents an increase in synaptic transmission and plasticity that underlies cognitive behaviors, and it is readily altered by $\mathrm{E}_{2}$ in many circumstances. In fact, application of an aromatase inhibitor eliminates CA LTP generated by theta-burst stimulation in intact female neurons, but not male or OVX animals, posing a potentially serious concern for women using aromatase inhibitors for therapeutic treatment of breast cancer [146]. $\mathrm{E}_{2}$ can also enhance or suppress long-term depression (LTD), reducing synaptic transmission, which may be dependent upon the specific receptors involved. In aged male CA1 cells, $\mathrm{E}_{2}$ decreased LTD [147]; however, $\mathrm{E}_{2}$ enhanced LTP in the cerebellum where $\operatorname{ER} \beta$ is the predominately expressed cognate receptor [148].

Although the majority of studies on cognitive process focus on the rapid effects of $E_{2}$, late-phase long-term potentiation (L-LTP), depends upon transcription and translation of new mRNA [149] to sustain an increase in synaptic transmission. $\mathrm{E}_{2}$ has been shown to regulate LTP in CA1 pyramidal cells [150] over the span of 48 hours, and this regulation appears to be dependent upon a higher ratio of NMDAR relative to AMPAR. LTP induction requires activation of NR2A-containing NMDARs; however, increased expression of NR2B potentiates LTP magnitude [151]. Notably, $E_{2}$ increased expression of NR2B mRNA and NR2B expression at the synapse $[152,153]$, and the $E_{2}$-induced increase in LTP can be abolished by blocking NR2B receptors [154], 
suggesting a transcriptional role for ERs in synaptic plasticity. Moreover, $\mathrm{E}_{2}$ application may increase CREB expression and the amount of phosphorylated CREB in regions such as the amygdala [155] and BNST $[117,155]$, which may be critical in the formation of long-term memories. Taken together, these data demonstrate that $\mathrm{E}_{2}$ regulates neuronal plasticity and memory through its original role as a transcription factor, and also by acting as a general intracellular signaling molecule through regulation of NMDARs and CREB. However, to date, there are little data on the mechanisms by which $\mathrm{ER} \beta$ regulates these processes, or how the same principles of plasticity may apply to other neurological issues.

\section{Estrogens and Mood Regulation}

A range of behavioral experiments indicate that $\mathrm{E}_{2}$ modulation of stress, mood, and affect is a complex story, with considerable conflicting data that may, as in other processes, be explained in part by distinct roles for ER $\alpha$ and ER $\beta$. Anecdotally, many women report mood fluctuations as corresponding to changes in circulating estrogen levels, such as what occurs during the menstrual cycle, peripuberty, postpartum, and peri/postmenopause. Incidence of anxiety and depression are observed at perimenopause and when hormone levels are fluctuating $[156,157]$. However, $\mathrm{E}_{2}$ can also exhibit anxiogenic properties, and often anxiety and depression present in a comorbid fashion, especially in women $[158,159]$. Interestingly, after the age of 55, bouts of depression and anxiety appear to decrease in women [160]. As previously mentioned, perimenopausal women receiving CEE in the KEEPs study reported an improvement in mood, and the primary actions of CEE tend to be mediated through $\operatorname{ER} \beta$ [20]. A plethora of behavioral studies has mounted in response to observational reports, and at first glance it appears that $\mathrm{ER} \beta$ has an anxiolytic and antidepressive role; however, there is still an immense void to be filled with respect to biochemical and molecular mechanisms of ER $\beta$ and affective disorders. Elucidating the precise molecular mechanisms that require $\mathrm{ER} \beta$ in plasticity and neurotransmitter processing in brain regions regulating these behaviors will help clarify the role of $\mathrm{E}_{2}$ in stress- and mood-related processes.

Contemporary hypotheses concerning the onset of affective disorders revolve around perturbations to the central processing of environmental stress. The hypothalamicpituitary-adrenal (HPA) axis is the 3-tiered hierarchical biological system that mediates physical or psychological response to stressors. The primary steroid regulating the HPA axis is cortisol/corticosterone (humans/rats, CORT), a glucocorticoid receptor (GR) ligand that is produced from the adrenals to exert negative feedback upon the HPA system to effectively modulate response to stressors. The paraventricular nucleus of hypothalamus (PVN) produces two neuropeptides, corticotropin-releasing hormone (CRH) and arginine vasopressin (AVP), to activate the HPA axis. CRF and AVP synergistically stimulate release of adrenocorticotropic hormone (ACTH) from the anterior pituitary, which acts on the adrenal cortex to produce CORT. CORT binds GR and negatively regulates CRF and AVP expressions and releases through classical negative feedback mechanisms $[161,162]$. ER $\beta$ is the main ER expressed in the PVN $[158,163-$ 165 ], and regulation of AVP is an interesting example of how ER action can vary. AVP expression fluctuates during the menstrual cycle and is usually highest when $\mathrm{E}_{2}$ is low. In fact, oral contraceptives appear to decrease AVP expression, and $\mathrm{E}_{2}$ is thought to inhibit AVP in the human SON [166]. In the rodent system, $\mathrm{ER} \beta$ and its splice variants activate the rodent AVP promoter independent of ligand [84]; however, the human promoter is repressed by $\mathrm{ER} \beta$ and splice variants. This discrepancy between the human and rat was mediated by an AP-1 response element on the human AVP promoter that is not present in the rat. Importantly, $\mathrm{ER} \beta$ acted similarly in the two systems when the AP-1 sequence was deleted from the human promoter, underscoring the striking alterations that small changes in DNA sequence can invoke in $\mathrm{E}_{2}$ signaling pathways and the importance of understanding the experimental context upon which such conclusions are based [77]. On the contrary, rat and human CRF expression was increased in response to $\mathrm{E}_{2}$ in rodent, monkey, and human hypothalamus, but it was inhibited in the placenta [167-170].

In addition to AVP and CRF, glutamatergic and GABAergic projects from regions like the BNST, AMY, PFC, and hippocampus all express $\operatorname{ER} \beta[45,46]$ and are likely targets for $E_{2}$ to exert effects on the HPA axis. Moreover, decreased $\mathrm{ER} \beta$ mRNA in postmortem locus coeruleus has been found to correlate with suicide [13], and, even more recently, $\mathrm{ER} \beta$-mediated hippocampal nitric oxide levels have been implicated in affective behaviors in females, but not males [171]. Neurotransmitter release from these regions influences mood, affect, and stress responses, and $\mathrm{E}_{2}$ increases the rate of monoamine oxidase degradation and serotonin transport which enhances serotonin at the synapse; $\mathrm{E}_{2}$ also increases serotonin receptor expression [172, 173]. Dopamine and serotonin [174] are diminished in the BNST, POA, and hippocampus and caudate putamen (dopamine) of $\beta$ ERKO mice [174] further implicating an important role for ER $\beta$ in the regulation of emotion and mood. $\beta$ ERKO mice also display serious morphological and functional abnormalities in the brain that correlate to increased depression and anxiety [12, $175-178]$. In addition to $\beta$ ERKO studies, administration of $\mathrm{ER} \beta$ selective agonists (diarylpoprionitrile, DPN) decreases both stress markers and anxiety-related behaviors in rats [158]. In fact, there have been several studies implicating $\mathrm{ER} \beta$ and its variants in affective behaviors, but the molecular mechanisms remain poorly understood.

\section{Summary}

Estrogen-receptor-mediated signaling in the brain regulates neurological processes, many of which translate to cognitive and affective behavioral outputs. When estrogen is declining and becomes replete, as in menopause, a number of neurophysiological changes occur, producing some unwanted changes. The most common and logical remedy is replacement of bioidentical hormone, $\mathrm{E}_{2}$; however, this treatment can be problematic depending upon the length 
of time a woman has been in a postmenopausal, estrogendeprived state. This suggests that there is a molecular switch in estrogen-mediated signaling that may allow for drastic change in ER signaling, not to mention the interaction of $\mathrm{E}_{2}$ signaling components and the natural aging process. These changes are likely to include alterations to receptor profiles including expression of alternatively spliced variants that respond differently to $\mathrm{E}_{2}$, changes in the cellular microenvironment that can alter the protein:protein associations which ultimately leads to changes in ER-mediated gene transcription, and synaptic transmission. $\mathrm{ER} \beta$ in particular is widely expressed and implicated positively in the regulation of memory and mood fluctuations, two of the most commonly reported neurological issues in postmenopausal women. It is important to understand the actions of $\operatorname{ER} \beta$ in the areas regulating these processes to identify what, when, how, and for whom hormone therapy may be a useful treatment to rectify cognitive and affective issues.

\section{Acknowledgments}

This work was supported by NIA RO1. AG033605-01 and, NIH T32 AG031780. The authors, N. N. Mott and T. R. Pak, have nothing to disclose.

\section{References}

[1] C. Bengtsson, O. Lindquist, and L. Redvall, "Is the menopausal age rapidly changing?” Maturitas, vol. 1, no. 3, pp. 159-164, 1979.

[2] A. Singh, S. Kaur, and I. Walia, "A historical perspective on menopause and menopausal age," Bulletin of the Indian Institute of History of Medicine (Hyderabad), vol. 32, no. 2, pp. 121-135, 2002.

[3] P. Verhaeghen and J. Cerella, "Aging, executive control, and attention: a review of meta-analyses," Neuroscience and Biobehavioral Reviews, vol. 26, no. 7, pp. 849-857, 2002.

[4] T. E. Wroolie, H. A. Kenna, K. E. Williams et al., "Differences in verbal memory performance in postmenopausal women receiving hormone therapy: $17 \beta$-estradiol versus conjugated equine estrogens," American Journal of Geriatric Psychiatry, vol. 19, no. 9, pp. 792-802, 2011.

[5] B. B. Sherwin, "Estrogenic effects on memory in women," Annals of the New York Academy of Sciences, vol. 743, pp. 213230, 1994 .

[6] B. B. Sherwin, "Hormones, mood, and cognitive functioning in postmenopausal women," Obstetrics and Gynecology, vol. 87, no. 2, supplement, pp. 20S-26S, 1996.

[7] B. B. Sherwin, "Sex hormones and psychological functioning in postmenopausal women," Experimental Gerontology, vol. 29, no. 3-4, pp. 423-430, 1994.

[8] S. M. Phillips and B. B. Sherwin, "Effects of estrogen on memory function in surgically menopausal women," Psychoneuroendocrinology, vol. 17, no. 5, pp. 485-495, 1992.

[9] R. Lindsay, J. M. Aitken, and J. B. Anderson, "Long term prevention of postmenopausal osteoporosis by oestrogen. Evidence for an increased bone mass after delayed onset of oestrogen treatment," The Lancet, vol. 1, no. 7968, pp. 1038-1040, 1976.

[10] J. E. Rossouw, R. L. Prentice, J. E. Manson et al., "Postmenopausal hormone therapy and risk of cardiovascular disease by age and years since menopause," The Journal of the
American Medical Association, vol. 297, no. 13, pp. 1465-1477, 2007.

[11] Q.-G. Zhang, D. Han, R.-M. Wang et al., "C terminus of Hsc70-interacting protein (CHIP)-mediated degradation of hippocampal estrogen receptor- $\alpha$ and the critical period hypothesis of estrogen neuroprotection," Proceedings of the National Academy of Sciences of the United States of America, vol. 108, no. 35, pp. E617-E624, 2011.

[12] W. Krezel, S. Dupont, A. Krust, P. Chambon, and P. F. Chapman, "Increased anxiety and synaptic plasticity in estrogen receptor $\beta$-deficient mice," Proceedings of the National Academy of Sciences of the United States of America, vol. 98, no. 21, pp. 1227812282, 2001.

[13] H. Östlund, E. Keller, and Y. L. Hurd, "Estrogen receptor gene expression in relation to neuropsychiatric disorders," Annals of the New York Academy of Sciences, vol. 1007, pp. 54-63, 2003.

[14] S. A. Shumaker, C. Legault, S. R. Rapp et al., "Estrogen plus progestin and the incidence of dementia and mild cognitive impairment in postmenopausal women: the Women's Health Initiative Memory Study: a randomized controlled trial," Journal of the American Medical Association, vol. 289, no. 20, pp. 2651-2662, 2003.

[15] S. A. Shumaker, C. Legault, L. Kuller et al., "Conjugated equine estrogens and incidence of probable dementia and mild cognitive impairment in postmenopausal women: women's Health Initiative Memory Study," Journal of the American Medical Association, vol. 291, no. 24, pp. 2947-2958, 2004.

[16] S. R. Rapp, M. A. Espeland, S. A. Shumaker et al., "Effect of estrogen plus progestin on global cognitive function in postmenopausal women: the Women's Health Initiative Memory Study: a randomized controlled trial," Journal of the American Medical Association, vol. 289, no. 20, pp. 2663-2672, 2003.

[17] V. W. Henderson, K. S. Benke, R. C. Green, L. A. Cupples, and L. A. Farrer, "Postmenopausal hormone therapy and Alzheimer's disease risk: interaction with age," Journal of Neurology, Neurosurgery and Psychiatry, vol. 76, no. 1, pp. 103-105, 2005.

[18] E. Garbe and S. Suissa, "Hormone replacement therapy and acute coronary syndromes: methodological issues between randomized and observational studies," Human Reproduction, vol. 19, no. 1, pp. 8-13, 2004.

[19] B. B. Braden, A. N. Garcia, S. E. Mennenga et al., "Cognitiveimpairing effects of medroxyprogesterone acetate in the rat: independent and interactive effects across time," Psychopharmacology, vol. 218, no. 2, pp. 405-418, 2011.

[20] B. R. Bhavnani, S.-P. Tam, and X. Lu, "Structure activity relationships and differential interactions and functional activity of various equine estrogens mediated via estrogen receptors (ERs) ER $\alpha$ and ER $\beta$," Endocrinology, vol. 149, no. 10, pp. 4857-4870, 2008.

[21] E. Hogervorst and S. Bandelow, "Sex steroids to maintain cognitive function in women after the menopause: a metaanalyses of treatment trials," Maturitas, vol. 66, no. 1, pp. 56-71, 2010.

[22] D. J. Mangelsdorf, C. Thummel, M. Beato et al., "The nuclear receptor super-family: the second decade," Cell, vol. 83, no. 6, pp. 835-839, 1995.

[23] E. V. Jensen, T. Suzuki, T. Kawashima, W. E. Stumpf, P. W. Jungblut, and E. R. DeSombre, "A two-step mechanism for the interaction of estradiol with rat uterus," Proceedings of the National Academy of Sciences of the United States of America, vol. 59, no. 2, pp. 632-638, 1968. 
[24] F. Naftolin, T. L. Horvath, R. L. Jakab, C. Leranth, N. Harada, and J. Balthazart, "Aromatase immunoreactivity in axon terminals of the vertebrate brain: an immunocytochemical study on quail, rat, monkey and human tissues," Neuroendocrinology, vol. 63, no. 2, pp. 149-155, 1996.

[25] C. E. Roselli, S. E. Abdelgadir, O. K. Rønnekleiv, and S. A. Klosterman, "Anatomic distribution and regulation of aromatase gene expression in the rat brain," Biology of Reproduction, vol. 58, no. 1, pp. 79-87, 1998.

[26] J. Balthazart and G. F. Ball, "Is brain estradiol a hormone or a neurotransmitter?" Trends in Neurosciences, vol. 29, no. 5, pp. 241-249, 2006.

[27] T. R. Pak, Y. S. Rao, S. A. Prins, and N. N. Mott, "An emerging role for microRNAs in sexually dimorphic neurobiological systems," Pflügers Archiv, vol. 465, no. 5, pp. 655-667, 2013.

[28] K. Yamagata, S. Fujiyama, S. Ito et al., "Maturation of microRNA is hormonally regulated by a nuclear receptor," Molecular Cell, vol. 36, no. 2, pp. 340-347, 2009.

[29] Y. Masuhiro, Y. Mezaki, M. Sakari et al., "Splicing potentiation by growth factor signals via estrogen receptor phosphorylation," Proceedings of the National Academy of Sciences of the United States of America, vol. 102, no. 23, pp. 8126-8131, 2005.

[30] A. Tremblay, G. B. Tremblay, F. Labrie, and V. Giguère, "LigandIndependent recruitment of SRC-1 to estrogen receptor $\beta$ through phosphorylation of activation function AF-1," Molecular Cell, vol. 3, no. 4, pp. 513-519, 1999.

[31] S. H. Meijsing, M. A. Pufall, A. Y. So, D. L. Bates, L. Chen, and K. R. Yamamoto, "DNA binding site sequence directs glucocorticoid receptor structure and activity," Science, vol. 324, no. 5925, pp. 407-410, 2009.

[32] W. Bourguet, P. Germain, and H. Gronemeyer, "Nuclear receptor ligand-binding domains: three-dimensional structures, molecular interactions and pharmacological implications," Trends in Pharmacological Sciences, vol. 21, no. 10, pp. 381-388, 2000.

[33] A. Koide, C. Zhao, M. Naganuma et al., "Identification of regions within the $\mathrm{F}$ domain of the human estrogen receptor $\alpha$ that are important for modulating transactivation and proteinprotein interactions," Molecular Endocrinology, vol. 21, no. 4, pp. 829-842, 2007.

[34] D. F. Skafar and S. Koide, "Understanding the human estrogen receptor-alpha using targeted mutagenesis," Molecular and Cellular Endocrinology, vol. 246, no. 1-2, pp. 83-90, 2006.

[35] E. C. Chang, J. Frasor, B. Komm, and B. S. Katzenellenbogen, "Impact of estrogen receptor $\beta$ on gene networks regulated by estrogen receptor $\alpha$ in breast cancer cells," Endocrinology, vol. 147, no. 10, pp. 4831-4842, 2006.

[36] X. Zhu, I. Leav, Y.-K. Leung et al., "Dynamic regulation of estrogen receptor- $\beta$ expression by DNA methylation during prostate cancer development and metastasis," American Journal of Pathology, vol. 164, no. 6, pp. 2003-2012, 2004.

[37] D. N. Petersen, G. T. Tkalcevic, P. H. Koza-Taylor, T. G. Turi, and T. A. Brown, "Identification of estrogen receptor $\beta 2$, a functional variant of estrogen receptor $\beta$ expressed in normal rat tissues," Endocrinology, vol. 139, no. 3, pp. 1082-1092, 1998.

[38] L. A. Helguero, M. H. Faulds, J.-Å. Gustafsson, and L.-A. Haldosén, "Estrogen receptors alfa $(\mathrm{ER} \alpha)$ and beta $(\mathrm{ER} \beta)$ differentially regulate proliferation and apoptosis of the normal murine mammary epithelial cell line HC11," Oncogene, vol. 24, no. 44, pp. 6605-6616, 2005.

[39] P. C. Kulakosky, M. A. McCarty, S. C. Jernigan, K. E. Risinger, and C. M. Klinge, "Response element sequence modulates estrogen receptor $\alpha$ and $\beta$ affinity and activity," Journal of Molecular Endocrinology, vol. 29, no. 1, pp. 137-152, 2002.

[40] O. M. V. Grober, M. Mutarelli, G. Giurato et al., "Global analysis of estrogen receptor beta binding to breast cancer cell genome reveals an extensive interplay with estrogen receptor alpha for target gene regulation," BMC Genomics, vol. 12, article 36, 2011.

[41] O. I. Vivar, X. Zhao, E. F. Saunier et al., "Estrogen receptor $\beta$ binds to and regulates three distinct classes of target genes," Journal of Biological Chemistry, vol. 285, no. 29, pp. 2205922066, 2010.

[42] G. G. J. M. Kuiper, E. Enmark, M. Pelto-Huikko, S. Nilsson, and J.-Å. Gustafsson, "Cloning of a novel estrogen receptor expressed in rat prostate and ovary," Proceedings of the National Academy of Sciences of the United States of America, vol. 93, no. 12, pp. 5925-5930, 1996.

[43] G. G. J. M. Kuiper, B. Carlsson, K. Grandien et al., "Comparison of the ligand binding specificity and transcript tissue distribution of estrogen receptors and $\alpha$ and $\beta$," Endocrinology, vol. 138, no. 3, pp. 863-870, 1997.

[44] D. B. Dubal, H. Zhu, J. Yu et al., "Estrogen receptor alpha, not beta, is a critical link in estradiol-mediated protection against brain injury," Proceedings of the National Academy of Sciences of the United States of America, vol. 98, no. 4, pp. 1952-1957, 2001.

[45] P. J. Shughrue, P. J. Scrimo, and I. Merchenthaler, "Evidence for the colocalization of estrogen receptor- $\beta$ mRNA and estrogen receptor- $\alpha$ immunoreactivity in neurons of the rat forebrain," Endocrinology, vol. 139, no. 12, pp. 5267-5270, 1998.

[46] P. J. Shughrue, M. V. Lane, and I. Merchenthaler, "Comparative distribution of estrogen receptor-alpha and -beta mRNA in the rat central nervous system," Journal of Comparative Neurology, vol. 388, no. 4, pp. 507-525, 1997.

[47] T. A. Milner, B. S. McEwen, S. Hayashi, C. J. Li, L. P. Reagan, and S. E. Alves, "Ultrastructural evidence that hippocampal alpha estrogen receptors are located at extranuclear sites," The Journal of Comparative Neurology, vol. 429, no. 3, pp. 355-371, 2001.

[48] T. A. Milner, L. S. Lubbers, S. E. Alves, and B. S. McEwen, "Nuclear and extranuclear estrogen binding sites in the rat forebrain and autonomic medullary areas," Endocrinology, vol. 149, no. 7, pp. 3306-3312, 2008.

[49] T. A. Milner, K. Ayoola, C. T. Drake et al., "Ultrastructural localization of estrogen receptor $\beta$ immunoreactivity in the rat hippocampal formation," Journal of Comparative Neurology, vol. 491, no. 2, pp. 81-95, 2005.

[50] A. E. Herbison and D. T. Theodosis, "Absence of estrogen receptor immunoreactivity in somatostatin (SRIF) neurons of the periventricular nucleus but sexually dimorphic colocalization of estrogen receptor and SRIF immunoreactivities in neurons of the bed nucleus of the stria terminalis," Endocrinology, vol. 132, no. 4, pp. 1707-1714, 1993.

[51] K. Kalita, S. Szymczak, and L. Kaczmarek, "Non-nuclear estrogen receptor $\beta$ and $\alpha$ in the hippocampus of male and female rats," Hippocampus, vol. 15, no. 3, pp. 404-412, 2005.

[52] T. Ivanova and C. Beyer, "Ontogenetic expression and sex differences of aromatase and estrogen receptor- $\alpha / \beta$ mRNA in the mouse hippocampus," Cell and Tissue Research, vol. 300, no. 2, pp. 231-237, 2000.

[53] C. Y. Pau, K.-Y. F. Pau, and H. G. Spies, "Putative estrogen receptor $\beta$ and $\alpha$ mRNA expression in male and female rhesus macaques," Molecular and Cellular Endocrinology, vol. 146, no. 1-2, pp. 59-68, 1998.

[54] A. L. Wijayaratne and D. P. McDonnell, "The human estrogen receptor- $\alpha$ is a ubiquitinated protein whose stability is affected 
differentially by agonists, antagonists, and selective estrogen receptor modulators," Journal of Biological Chemistry, vol. 276, no. 38, pp. 35684-35692, 2001.

[55] V. Bartella, P. Rizza, I. Barone et al., "Estrogen receptor beta binds Sp1 and recruits a corepressor complex to the estrogen receptor alpha gene promoter," Breast Cancer Research and Treatment, vol. 134, no. 2, pp. 569-581, 2012.

[56] L. C. Li, C. C. Yeh, D. Nojima, and R. Dahiya, "Cloning and characterization of human estrogen receptor beta promoter," Biochemical and Biophysical Research Communications, vol. 275, no. 2, pp. 682-689, 2000.

[57] E. A. Vladusic, A. E. Hornby, F. K. Guerra-Vladusic, J. Lakins, and R. Lupu, "Expression and regulation of estrogen receptor $ß$ in human breast tumors and cell lines," Oncology Reports, vol. 7, no. 1, pp. 157-167, 2000.

[58] T. Hatsumi and Y. Yamamuro, "Downregulation of estrogen receptor gene expression by exogenous $17 \beta$-estradiol in the mammary glands of lactating mice," Experimental Biology and Medicine, vol. 231, no. 3, pp. 311-316, 2006.

[59] H. B. Patisaul, P. L. Whitten, and L. J. Young, "Regulation of estrogen receptor beta mRNA in the brain: opposite effects of $17 \beta$-estradiol and the phytoestrogen, coumestrol," Molecular Brain Research, vol. 67, no. 1, pp. 165-171, 1999.

[60] T. J. Brown, N. J. MacLusky, M. Shanabrough, and F. Naftolin, "Comparison of age- and sex-related changes in cell nuclear estrogen-binding capacity and progestin receptor induction in the rat brain," Endocrinology, vol. 126, no. 6, pp. 2965-2972, 1990.

[61] B. S. Rubin, T. O. Fox, and R. S. Bridges, "Estrogen binding in nuclear and cytosolic extracts from brain and pituitary of middle-aged female rats," Brain Research, vol. 383, no. 1-2, pp. 60-67, 1986.

[62] T. Funabashi, S. P. Kleopoulos, P. J. Brooks et al., "Changes in estrogenic regulation of estrogen receptor $\alpha$ mRNA and progesterone receptor mRNA in the female rat hypothalamus during aging: an in situ hybridization study," Neuroscience Research, vol. 38, no. 1, pp. 85-92, 2000.

[63] M. E. Wilson, K. L. Rosewell, M. L. Kashon, P. J. Shughrue, I. Merchenthaler, and P. M. Wise, "Age differentially influences estrogen receptor- $\alpha(\mathrm{ER} \alpha)$ and estrogen receptor- $\beta(\mathrm{ER} \beta)$ gene expression in specific regions of the rat brain," Mechanisms of Ageing and Development, vol. 123, no. 6, pp. 593-601, 2002.

[64] W. S. Post, P. J. Goldschmidt-Clermont, C. C. Wilhide et al., "Methylation of the estrogen receptor gene is associated with aging and atherosclerosis in the cardiovascular system," Cardiovascular Research, vol. 43, no. 4, pp. 985-991, 1999.

[65] J.-P. J. Issa, Y. L. Ottaviano, P. Celano, S. R. Hamilton, N. E. Davidson, and S. B. Baylin, "Methylation of the oestrogen receptor CpG island links ageing and neoplasia in human colon," Nature Genetics, vol. 7, no. 4, pp. 536-540, 1994.

[66] T. Funabashi and F. Kimura, "Effects of estrogen and estrogen receptor messenger RNA levels in young and middle-aged female rats: comparison of medial preoptic area and mediobasal hypothalamus," Acta Biologica Hungarica, vol. 45, no. 2-4, pp. 223-231, 1994.

[67] M. A. Miller, P. E. Kolb, B. Planas, and M. A. Raskind, "Estrogen receptor and neurotensin/neuromedin- $\mathrm{N}$ gene expression in the preoptic area are unaltered with age in Fischer 344 female rats," Endocrinology, vol. 135, no. 5, pp. 1986-1995, 1994.

[68] T. R. Chakraborty, P. R. Hof, L. Ng, and A. C. Gore, "Stereologic analysis of estrogen receptor alpha (ER alpha) expression in rat hypothalamus and its regulation by aging and estrogen," Journal of Comparative Neurology, vol. 466, no. 3, pp. 409-421, 2003.

[69] J. M. Westberry, A. L. Trout, and M. E. Wilson, "Epigenetic regulation of estrogen receptor beta expression in the rat cortex during aging," NeuroReport, vol. 22, no. 9, pp. 428-432, 2011.

[70] T. R. Chakraborty, L. Ng, and A. C. Gore, "Age-related changes in estrogen receptor $\beta$ in rat hypothalamus: a quantitative analysis," Endocrinology, vol. 144, no. 9, pp. 4164-4171, 2003.

[71] I. Poola, S. Koduri, S. Chatra, and R. Clarke, "Identification of twenty alternatively spliced estrogen receptor alpha mRNAs in breast cancer cell lines and tumors using splice targeted primer approach," Journal of Steroid Biochemistry and Molecular Biology, vol. 72, no. 5, pp. 249-258, 2000.

[72] T. A. Ishunina and D. F. Swaab, "Hippocampal estrogen receptor-alpha splice variant TADDI in the human brain in aging and Alzheimer's disease," Neuroendocrinology, vol. 89, no. 2, pp. 187-199, 2009.

[73] T. A. Ishunina and D. F. Swaab, "Estrogen receptor- $\alpha$ splice variants in the human brain," Gynecological Endocrinology, vol. 24, no. 2, pp. 93-98, 2008.

[74] T. A. Ishunina, F. P. M. Kruijver, R. Balesar, and D. F. Swaab, "Differential expression of estrogen receptor $\alpha$ and $\beta$ immunoreactivity in the human supraoptic nucleus in relation to sex and aging," Journal of Clinical Endocrinology and Metabolism, vol. 85, no. 9, pp. 3283-3291, 2000.

[75] T. A. Ishunina, D. F. Fischer, and D. F. Swaab, "Estrogen receptor $\alpha$ and its splice variants in the hippocampus in aging and Alzheimer's disease," Neurobiology of Aging, vol. 28, no. 11, pp. 1670-1681, 2007.

[76] J. R. Tollervey, Z. Wang, T. Hortobágyi et al., "Analysis of alternative splicing associated with aging and neurodegeneration in the human brain," Genome Research, vol. 21, no. 10, pp. 15721582, 2011.

[77] N. N. Mott and T. R. Pak, "Characterisation of human oestrogen receptor beta $(\mathrm{ER} \beta)$ splice variants in neuronal cells," Journal of Neuroendocrinology, vol. 24, no. 10, pp. 1311-1321, 2012.

[78] S. Inoue, S.-J. Hoshino, H. Miyoshi et al., "Identification of a ovel isoform of estrogen receptor, a potential inhibitor of estrogen action, in vascular smooth muscle cells," Biochemical and Biophysical Research Communications, vol. 219, no. 3, pp. 766-772, 1996.

[79] J. K. Skipper, L. J. Young, J. M. Bergeron, M. T. Tetzlaff, C. T. Osborn, and D. Crews, "Identification of an isoform of the estrogen receptor messenger RNA lacking exon four and present in the brain," Proceedings of the National Academy of Sciences of the United States of America, vol. 90, no. 15, pp. 71727175, 1993.

[80] R. H. Price Jr., N. Lorenzon, and R. J. Handa, "Differential expression of estrogen receptor beta splice variants in rat brain: identification and characterization of a novel variant missing exon 4," Brain Research. Molecular Brain Research, vol. 80, no. 2, pp. 260-268, 2000.

[81] S. Chu and P. J. Fuller, "Identification of a splice variant of the rat estrogen receptor $\beta$ gene," Molecular and Cellular Endocrinology, vol. 132, no. 1-2, pp. 195-199, 1997.

[82] B. Lu, E. Leygue, H. Dotzlaw, L. J. Murphy, L. C. Murphy, and P. H. Watson, "Estrogen receptor- $\beta$ mRNA variants in human and murine tissues," Molecular and Cellular Endocrinology, vol. 138, no. 1-2, pp. 199-203, 1998.

[83] T. R. Pak, W. C. J. Chung, J. L. Roberts, and R. J. Handa, "Ligand-independent effects of estrogen receptor $\beta$ on 
mouse gonadotropin-releasing hormone promoter activity," Endocrinology, vol. 147, no. 4, pp. 1924-1931, 2006.

[84] T. R. Pak, W. C. J. Chung, L. R. Hinds, and R. J. Handa, "Estrogen receptor- $\beta$ mediates dihydrotestosterone-induced stimulation of the arginine vasopressin promoter in neuronal cells," Endocrinology, vol. 148, no. 7, pp. 3371-3382, 2007.

[85] Y. K. Leung, P. Mak, S. Hassan, and S. M. Ho, "Estrogen receptor (ER)- $\beta$ isoforms: a key to understanding ER- $\beta$ signaling," Proceedings of the National Academy of Sciences of the United States of America, vol. 103, no. 35, pp. 13162-13167, 2006.

[86] J. M. Wang, X. Hou, S. Adeosun et al., "A dominant negative ER $\beta$ splice variant determines the effectiveness of early or late estrogen therapy after ovariectomy in rats," PLoS One, vol. 7, no. 3, Article ID e33493, 2012.

[87] W. C. J. Chung, T. R. Pak, S. Suzuki, W. A. Pouliot, M. E. Andersen, and R. J. Handa, "Detection and localization of an estrogen receptor beta splice variant protein (ER $\beta 2)$ in the adult female rat forebrain and midbrain regions," Journal of Comparative Neurology, vol. 505, no. 3, pp. 249-267, 2007.

[88] R. H. Price Jr., C. A. Butler, P. Webb, R. Uht, P. Kushner, and R. J. Handa, "A splice variant of estrogen receptor $\beta$ missing exon 3 displays altered subnuclear localization and capacity for transcriptional activation," Endocrinology, vol. 142, no. 5, pp. 2039-2049, 2001.

[89] Y. Wang and R. J. Miksicek, "Identification of a dominant negative form of the human estrogen receptor," Molecular Endocrinology, vol. 5, no. 11, pp. 1707-1715, 1991.

[90] E. Küppers and C. Beyer, "Expression of estrogen receptor- $\alpha$ and $\beta$ mRNA in the developing and adult mouse striatum," Neuroscience Letters, vol. 276, no. 2, pp. 95-98, 1999.

[91] C. Gundlah, S. G. Kohama, S. J. Mirkes, V. T. Garyfallou, H. F. Urbanski, and C. L. Bethea, "Distribution of estrogen receptor beta $(\mathrm{ER} \beta)$ mRNA in hypothalamus, midbrain and temporal lobe of spayed macaque: continued expression with hormone replacement," Brain Research. Molecular Brain Research, vol. 76, no. 2, pp. 191-204, 2000.

[92] Y. Morishima, P. J. M. Murphy, D.-P. Li, E. R. Sanchez, and W. B. Pratt, "Stepwise assembly of a glucocorticoid receptor.hsp90 heterocomplex resolves two sequential ATP-dependent events involving first hsp70 and then hsp90 in opening of the steroid binding pocket," Journal of Biological Chemistry, vol. 275, no. 24, pp. 18054-18060, 2000.

[93] K. D. Dittmar and W. B. Pratt, "Folding of the glucocorticoid receptor by the reconstituted hsp90-based chaperone machinery. The initial hsp90.p60.hsp70-dependent step is sufficient for creating the steroid binding conformation," Journal of Biological Chemistry, vol. 272, no. 20, pp. 13047-13054, 1997.

[94] K. I. Kang, X. Meng, J. Devin-Leclerc et al., "The molecular chaperone Hsp90 can negatively regulate the activity of a glucocorticosteroid-dependent promoter," Proceedings of the National Academy of Sciences of the United States of America, vol. 96, no. 4, pp. 1439-1444, 1999.

[95] K. Unno, H. Asakura, Y. Shibuya, M. Kaiho, S. Okada, and N. Oku Naoto, "Increase in basal level of Hsp70, consisting chiefly of constitutively expressed hsp70 (Hsc70) in aged rat brain," Journals of Gerontology. Series A, vol. 55, no. 7, pp. B329-B335, 2000.

[96] U. E. Olazabal, D. W. Pfaff, and C. V. Mobbs, "Sex differences in the regulation of heat shock protein $70 \mathrm{kDa}$ and $90 \mathrm{kDa}$ in the rat ventromedial hypothalamus by estrogen," Brain Research, vol. 596, no. 1-2, pp. 311-314, 1992.
[97] M. A. Pahlavani, M. D. Harris, S. A. Moore, and A. Richardson, "Expression of heat shock protein 70 in rat spleen lymphocytes is affected by age but not by food restriction," Journal of Nutrition, vol. 126, no. 9, pp. 2069-2075, 1996.

[98] A. R. Heydari, B. Wu, R. Takahashi, R. Strong, and A. Richardson, "Expression of heat shock protein 70 is altered by age and diet at the level of transcription," Molecular and Cellular Biology, vol. 13, no. 5, pp. 2909-2918, 1993.

[99] M. Sabbah, K.-I. I. Kang, L. Tora, and G. Redeuilh, "Oestrogen receptor facilitates the formation of preinitiation complex assembly: involvement of the general transcription factor TFIIB," Biochemical Journal, vol. 336, part 3, pp. 639-646, 1998.

[100] S.-Y. Wu, M. C. Thomas, S. Y. Hou, V. Likhite, and C.-M. Chiang, "Isolation of mouse TFIID and functional characterization of TBP and TFIID in mediating estrogen receptor and chromatin transcription," Journal of Biological Chemistry, vol. 274, no. 33, pp. 23480-23490, 1999.

[101] S. Ghosh and M. K. Thakur, "Tissue-specific expression of receptor-interacting protein in aging mouse," Age, vol. 30, no. 4, pp. 237-243, 2008.

[102] J. Frasor, J. M. Danes, B. Komm, K. C. N. Chang, C. Richard Lyttle, and B. S. Katzenellenbogen, "Profiling of estrogen up- and down-regulated gene expression in human breast cancer cells: insights into gene networks and pathways underlying estrogenic control of proliferation and cell phenotype," Endocrinology, vol. 144, no. 10, pp. 4562-4574, 2003.

[103] J. Frasor, J. M. Danes, C. C. Funk, and B. S. Katzenellenbogen, "Estrogen down-regulation of the corepressor N-CoR: mechanism and implications for estrogen derepression of $\mathrm{N}$ CoR-regulated genes," Proceedings of the National Academy of Sciences of the United States of America, vol. 102, no. 37, pp. 13153-13157, 2005.

[104] N. J. McKenna and B. W. O'Malley, "Combinatorial control of gene expression by nuclear receptors and coregulators," Cell, vol. 108, no. 4, pp. 465-474, 2002.

[105] T.-P. Yao, G. Ku, N. Zhou, R. Scully, and D. M. Livingston, "The nuclear hormone receptor coactivator SRC-1 is a specific target of p300," Proceedings of the National Academy of Sciences of the United States of America, vol. 93, no. 20, pp. 10626-10631, 1996.

[106] B. Hanstein, R. Eckner, J. DiRenzo et al., "p300 is a component of an estrogen receptor coactivator complex," Proceedings of the National Academy of Sciences of the United States of America, vol. 93, no. 21, pp. 11540-11545, 1996.

[107] S. Halachmi, E. Marden, G. Martin, H. MacKay, C. Abbondanza, and M. Brown, "Estrogen receptor-associated proteins: possible mediators of hormone-induced transcriptions," Science, vol. 264, no. 5164, pp. 1455-1458, 1994.

[108] A. J. Horlein, A. M. Naar, T. Heinzel et al., "Ligand-independent repression by the thyroid hormone receptor mediated by a nuclear receptor co-repressor," Nature, vol. 377, no. 6548, pp. 397-404, 1995.

[109] J. D. Chen and R. M. Evans, "A transcriptional co-repressor that interacts with nuclear hormone receptors," Nature, vol. 377, no. 6548, pp. 454-457, 1995.

[110] A. Malovannaya, R. B. Lanz, S. Y. Jung et al., "Analysis of the human endogenous coregulator complexome," Cell, vol. 145, no. 5, pp. 787-799, 2011.

[111] Z. Nawaz, D. M. Lonard, C. L. Smith et al., "The Angelman syndrome-associated protein, E6-AP, is a coactivator for the nuclear hormone receptor superfamily," Molecular and Cellular Biology, vol. 19, no. 2, pp. 1182-1189, 1999. 
[112] B. Zheng, M. Han, M. Bernier, and J.-K. Wen, "Nuclear actin and actin-binding proteins in the regulation of transcription and gene expression," FEBS Journal, vol. 276, no. 10, pp. 26692685, 2009.

[113] W. A. Hofmann, L. Stojiljkovic, B. Fuchsova et al., "Actin is part of pre-initiation complexes and is necessary for transcription by RNA polymerase II," Nature Cell Biology, vol. 6, no. 11, pp. 10941101, 2004.

[114] K. Tokunaga, T. Shibuya, Y. Ishihama et al., "Nucleocytoplasmic transport of fluorescent mRNA in living mammalian cells: nuclear mRNA export is coupled to ongoing gene transcription," Genes to Cells, vol. 11, no. 3, pp. 305-317, 2006.

[115] R. Métivier, G. Penot, M. R. Hübner et al., "Estrogen receptor$\alpha$ directs ordered, cyclical, and combinatorial recruitment of cofactors on a natural target promoter," Cell, vol. 115, no. 6, pp. 751-763, 2003.

[116] C. Ambrosino, R. Tarallo, A. Bamundo et al., "Identification of a hormone-regulated dynamic nuclear actin network associated with estrogen receptor $\alpha$ in human breast cancer cell nuclei," Molecular and Cellular Proteomics, vol. 9, no. 6, pp. 1352-1367, 2010.

[117] F. Shao, R. Zhang, L. Dong, and K. Ying, "Overexpression of gelsolin-like actin-capping protein is associated with progression of lung adenocarcinoma," Tohoku Journal of Experimental Medicine, vol. 225, no. 2, pp. 95-101, 2011.

[118] K. Nishimura, H.-J. Ting, Y. Harada et al., "Modulation of androgen receptor transactivation by gelsolin: a newly identified androgen receptor coregulator," Cancer Research, vol. 63, no. 16, pp. 4888-4894, 2003.

[119] J. S. Ahn, I. S. Jang, D. I. Kim et al., "Aging-associated increase of gelsolin for apoptosis resistance," Biochemical and Biophysical Research Communications, vol. 312, no. 4, pp. 1335-1341, 2003.

[120] I. Nalvarte, T. Schwend, and J.-Å. Gustafsson, "Proteomics analysis of the estrogen receptor $\alpha$ receptosome," Molecular and Cellular Proteomics, vol. 9, no. 7, pp. 1411-1422, 2010.

[121] L.-H. Miau, C.-J. Chang, B.-J. Shen, W.-H. Tsai, and S.-C. Lee, "Identification of heterogeneous nuclear ribonucleoprotein $\mathrm{K}$ (hnRNP K) as a repressor of C/EBP $\beta$-mediated gene activation," Journal of Biological Chemistry, vol. 273, no. 17, pp. 10784-10791, 1998.

[122] A. Ostareck-Lederer, D. H. Ostareck, C. Cans et al., "c-Srcmediated phosphorylation of hnRNP $\mathrm{K}$ drives translational activation of specifically silenced mRNAs," Molecular and Cellular Biology, vol. 22, no. 13, pp. 4535-4543, 2002.

[123] P. S. Bagga, G. K. Arhin, and J. Wilusz, "DSEF-1 is a member of the hnRNP $\mathrm{H}$ family of RNA-binding proteins and stimulates pre-mRNA cleavage and polyadenylation in vitro," Nucleic Acids Research, vol. 26, no. 23, pp. 5343-5350, 1998.

[124] V. Markovtsov, J. M. Nikolic, J. A. Goldman, C. W. Turck, M.Y. Chou, and D. L. Black, "Cooperative assembly of an hnRNP complex induced by a tissue-specific homolog of polypyrimidine tract binding protein," Molecular and Cellular Biology, vol. 20, no. 20, pp. 7463-7479, 2000.

[125] S. Y. Jung, A. Malovannaya, J. Wei, B. W. O’Malley, and J. Qin, "Proteomic analysis of steady-state nuclear hormone receptor coactivator complexes," Molecular Endocrinology, vol. 19, no. 10, pp. 2451-2465, 2005.

[126] W. Hong, R. J. Resnick, C. Rakowski, D. Shalloway, S. J. Taylor, and G. A. Blobel, "Physical and functional interaction between the transcriptional cofactor $\mathrm{CBP}$ and the $\mathrm{KH}$ domain protein Sam68," Molecular Cancer Research, vol. 1, no. 1, pp. 48-55, 2002.
[127] R. Shao, X. Wang, B. Weijdegård et al., "Coordinate regulation of heterogeneous nuclear ribonucleoprotein dynamics by steroid hormones in the human fallopian tube and endometrium in vivo and in vitro," American Journal of Physiology, vol. 302, no. 10, pp. E1269-E1282, 2012.

[128] C. S. Woolley and B. S. McEwen, "Estradiol mediates fluctuation in hippocampal synapse density during the estrous cycle in the adult rat," Journal of Neuroscience, vol. 12, no. 7, pp. 2549-2554, 1992.

[129] C. S. Woolley, H. J. Wenzel, and P. A. Schwartzkroin, "Estradiol increases the frequency of multiple synapse boutons in the hippocampal CA1 region of the adult female rat," The Journal of Comparative Neurology, vol. 373, no. 1, pp. 108-117, 1996.

[130] C. S. Woolley, "Estrogen-mediated structural and functional synaptic plasticity in the female rat hippocampus," Hormones and Behavior, vol. 34, no. 2, pp. 140-148, 1998.

[131] D. P. Srivastava, K. M. Woolfrey, K. A. Jones et al., "Rapid enhancement of two-step wiring plasticity by estrogen and NMDA receptor activity," Proceedings of the National Academy of Sciences of the United States of America, vol. 105, no. 38, pp. 14650-14655, 2008.

[132] M. Ogiue-Ikeda, N. Tanabe, H. Mukai et al., "Rapid modulation of synaptic plasticity by estrogens as well as endocrine disrupters in hippocampal neurons," Brain Research Reviews, vol. 57, no. 2, pp. 363-375, 2008.

[133] N. J. Sandstrom and C. L. Williams, "Spatial memory retention is enhanced by acute and continuous estradiol replacement," Hormones and Behavior, vol. 45, no. 2, pp. 128-135, 2004.

[134] E. Hogervorst, J. Williams, M. Budge, W. Riedel, and J. Jolles, "The nature of the effect of female gonadal hormone replacement therapy on cognitive function in post-menopausal women: a meta-analysis," Neuroscience, vol. 101, no. 3, pp. 485$512,2000$.

[135] M. E. Bailey, A. C. J. Wang, J. Hao et al., "Interactive effects of age and estrogen on cortical neurons: implications for cognitive aging," Neuroscience, vol. 191, pp. 148-158, 2011.

[136] A. A. Walf, M. E. Rhodes, and C. A. Frye, "Ovarian steroids enhance object recognition in naturally cycling and ovariectomized, hormone-primed rats," Neurobiology of Learning and Memory, vol. 86, no. 1, pp. 35-46, 2006.

[137] V. N. Luine, L. F. Jacome, and N. J. Maclusky, "Rapid enhancement of visual and place memory by estrogens in rats," Endocrinology, vol. 144, no. 7, pp. 2836-2844, 2003.

[138] L. Fan, Z. Zhao, P. T. Orr, C. H. Chambers, M. C. Lewis, and K. M. Frick, "Estradiol-induced object memory consolidation in middle-aged female mice requires dorsal hippocampal extracellular signal-regulated kinase and phosphatidylinositol 3-kinase activation," Journal of Neuroscience, vol. 30, no. 12, pp. 43904400,2010

[139] D. B. Dubal and P. M. Wise, "Neuroprotective effects of estradiol in middle-aged female rats," Endocrinology, vol. 142, no. 1, pp. 43-48, 2001.

[140] S.-H. Yang, J. Shi, A. L. Day, and J. W. Simpkins, "Estradiol exerts neuroprotective effects when administered after ischemic insult," Stroke, vol. 31, no. 3, pp. 745-750, 2000.

[141] J. W. Simpkins, G. Rajakumar, Y.-Q. Zhang et al., "Estrogens may reduce mortality and ischemic damage caused by middle cerebral artery occlusion in the female rat," Journal of Neurosurgery, vol. 87, no. 5, pp. 724-730, 1997.

[142] J. Shi, K. S. Panickar, S.-H. Yang, O. Rabbani, A. L. Day, and J. W. Simpkins, "Estrogen attenuates over-expression of $\beta$-amyloid 
precursor protein messager RNA in an animal model of focal ischemia," Brain Research, vol. 810, no. 1-2, pp. 87-92, 1998.

[143] Q.-H. Zhang, Y.-H. Huang, Y.-Z. Hu et al., "Disruption of estrogen receptor beta in mice brain results in pathological alterations resembling Alzheimer disease," Acta Pharmacologica Sinica, vol. 25, no. 4, pp. 452-457, 2004.

[144] E. F. Rissman, A. L. Heck, J. E. Leonard, M. A. Shupnik, and J.$\AA$ A. Gustafsson, "Disruption of estrogen receptor $\beta$ gene impairs spatial learning in female mice," Proceedings of the National Academy of Sciences of the United States of America, vol. 99, no. 6, pp. 3996-4001, 2002.

[145] M. Day, A. Sung, S. Logue, M. Bowlby, and R. Arias, "Beta estrogen receptor knockout (BERKO) mice present attenuated hippocampal CA1 long-term potentiation and related memory deficits in contextual fear conditioning," Behavioural Brain Research, vol. 164, no. 1, pp. 128-131, 2005.

[146] R. Vierk, G. Glassmeier, L. Zhou et al., "Aromatase inhibition abolishes LTP generation in female but not in male mice," The Journal of Neuroscience, vol. 32, no. 24, pp. 8116-8126, 2012.

[147] R.-M. Vouimba, M. R. Foy, J. G. Foy, and R. F. Thompson, “17 $\beta$ estradiol suppresses expression of long-term depression in aged rats," Brain Research Bulletin, vol. 53, no. 6, pp. 783-787, 2000.

[148] C. E. Andreescu, B. A. Milojkovic, E. D. Haasdijk et al., "Estradiol improves cerebellar memory formation by activating estrogen receptor $\beta$," Journal of Neuroscience, vol. 27, no. 40, pp. 10832-10839, 2007.

[149] Y.-Y. Huang, P. V. Nguyen, T. Abel, and E. R. Kandel, "Longlasting forms of synaptic potentiation in the mammalian hippocampus," Learning Memory, vol. 3, no. 2-3, pp. 74-85, 1996.

[150] H. Mukai, T. Tsurugizawa, G. Murakami et al., "Rapid modulation of long-term depression and spinogenesis via synaptic estrogen receptors in hippocampal principal neurons," Journal of Neurochemistry, vol. 100, no. 4, pp. 950-967, 2007.

[151] L. Liu, T. P. Wong, M. F. Pozza et al., "Role of NMDA receptor subtypes in governing the direction of hippocampal synaptic plasticity," Science, vol. 304, no. 5673, pp. 1021-1024, 2004.

[152] M. Cyr, O. Ghribi, C. Thibault, M. Morissette, M. Landry, and T. di Paolo, "Ovarian steroids and selective estrogen receptor modulators activity on rat brain NMDA and AMPA receptors," Brain Research Reviews, vol. 37, no. 1-3, pp. 153-161, 2001.

[153] M. M. Adams, S. E. Fink, W. G. M. Janssen, R. A. Shah, and J. H. Morrison, "Estrogen modulates synaptic N-methyl-D-aspartate receptor subunit distribution in the aged hippocampus," Journal of Comparative Neurology, vol. 474, no. 3, pp. 419-426, 2004.

[154] C. C. Smith and L. L. McMahon, "Estradiol-induced increase in the magnitude of long-term potentiation is prevented by blocking NR2B-containing receptors," Journal of Neuroscience, vol. 26, no. 33, pp. 8517-8522, 2006.

[155] Y. Zhou, J. J. Watters, and D. M. Dorsa, "Estrogen rapidly induces the phosphorylation of the cAMP response element binding protein in rat brain," Endocrinology, vol. 137, no. 5, pp. 2163-2166, 1996.

[156] X. Gonda, T. Telek, G. Juhász, J. Lazary, A. Vargha, and G. Bagdy, "Patterns of mood changes throughout the reproductive cycle in healthy women without premenstrual dysphoric disorders," Progress in Neuro-Psychopharmacology and Biological Psychiatry, vol. 32, no. 8, pp. 1782-1788, 2008.

[157] E. W. Freeman, "Premenstrual syndrome and premenstrual dysphoric disorder: definitions and diagnosis," Psychoneuroendocrinology, vol. 28, supplement 3, pp. 25-37, 2003.
[158] T. D. Lund, T. Rovis, W. C. J. Chung, and R. J. Handa, "Novel actions of estrogen receptor- $\beta$ on anxiety-related behaviors," Endocrinology, vol. 146, no. 2, pp. 797-807, 2005.

[159] N. Breslau, L. Schultz, and E. Peterson, "Sex differences in depression: a role for preexisting anxiety," Psychiatry Research, vol. 58, no. 1, pp. 1-12, 1995.

[160] P. E. Bebbington, G. Dunn, R. Jenkins et al., "The influence of age and sex on the prevalence of depressive conditions: report from the National Survey of Psychiatric Morbidity," Psychological Medicine, vol. 28, no. 1, pp. 9-19, 1998.

[161] G. Aguilera, J. P. Harwood, and J. X. Wilson, "Mechanisms of action of corticotropin-releasing factor and other regulators of corticotropin release in rat pituitary cells," Journal of Biological Chemistry, vol. 258, no. 13, pp. 8039-8045, 1983.

[162] A. Papadimitriou and K. N. Priftis, "Regulation of the hypothalamic-pituitary-adrenal axis," NeuroImmunoModulation, vol. 16, no. 5, pp. 265-271, 2009.

[163] S. Suzuki and R. J. Handa, "Regulation of estrogen receptor- $\beta$ expression in the female rat hypothalamus: differential effects of dexamethasone and estradiol," Endocrinology, vol. 145, no. 8, pp. 3658-3670, 2004.

[164] W. J. S. Miller, S. Suzuki, L. K. Miller, R. Handa, and R. M. Uht, "Estrogen receptor (ER) $\beta$ isoforms rather than $\mathrm{ER} \alpha$ regulate corticotropin-releasing hormone promoter activity through an alternate pathway," Journal of Neuroscience, vol. 24, no. 47, pp. 10628-10635, 2004.

[165] C. Isgor, M. Cecchi, M. Kabbaj, H. Akil, and S. J. Watson, "Estrogen receptor $\beta$ in the paraventricular nucleus of hypothalamus regulates the neuroendocrine response to stress and is regulated by corticosterone," Neuroscience, vol. 121, no. 4, pp. 837-845, 2003.

[166] M. L. Forsling, I. Kalló, D. E. Hartley et al., “Oestrogen receptor$\beta$ and neurohypophysial hormones: functional interaction and neuroanatomical localisation," Pharmacology Biochemistry and Behavior, vol. 76, no. 3-4, pp. 535-542, 2003.

[167] A. S. Lalmansingh and R. M. Uht, "Estradiol regulates corticotropin-releasing hormone gene (crh) expression in a rapid and phasic manner that parallels estrogen receptor- $\alpha$ and - $\beta$ recruitment to a $3^{\prime}, 5^{\prime}$-cyclic adenosine $5^{\prime}$ - monophosphate regulatory region of the proximal crh promoter," Endocrinology, vol. 149, no. 1, pp. 346-357, 2008.

[168] B. N. Roy, R. L. Reid, and D. A. van Vugt, "The effects of estrogen and progesterone on corticotropin-releasing hormone and arginine vasopressin messenger ribonucleic acid levels in the paraventricular nucleus and supraoptic nucleus of the rhesus monkey," Endocrinology, vol. 140, no. 5, pp. 2191-2198, 1999.

[169] X. Ni, R. C. Nicholson, B. R. King, E.-C. Chan, M. A. Read, and R. Smith, "Estrogen represses whereas the estrogen-antagonist ICI 182780 stimulates placental CRH gene expression," Journal of Clinical Endocrinology and Metabolism, vol. 87, no. 8, pp. 3774-3778, 2002.

[170] N. C. Vamvakopoulos and G. P. Chrousos, "Evidence of direct estrogenic regulation of human corticotropin-releasing hormone gene expression. Potential implications for the sexual dimophism of the stress response and immune/inflammatory reaction," Journal of Clinical Investigation, vol. 92, no. 4, pp. 1896-1902, 1993.

[171] Y. Hu, D. L. Wu, C. X. Luo et al., "Hippocampal nitric oxide contributes to sex difference in affective behaviors," Proceedings of the National Academy of Sciences of the United States of America, vol. 109, no. 35, pp. 14224-14229, 2012. 
[172] B. E. H. Sumner and G. Fink, "Estrogen increases the density of 5-hydroxytryptamine(2A) receptors in cerebral cortex and nucleus accumbens in the female rat," Journal of Steroid Biochemistry and Molecular Biology, vol. 54, no. 1-2, pp. 15-20, 1995.

[173] L. J. Smith, J. A. Henderson, C. W. Abell, and C. L. Bethea, "Effects of ovarian steroids and raloxifene on proteins that synthesize, transport, and degrade serotonin in the raphe region of macaques," Neuropsychopharmacology, vol. 29, no. 11, pp. 2035-2045, 2004.

[174] D. B. Imwalle, J.-Å. Gustafsson, and E. F. Rissman, "Lack of functional estrogen receptor $\beta$ influences anxiety behavior and serotonin content in female mice," Physiology and Behavior, vol. 84, no. 1, pp. 157-163, 2005.

[175] K. Tomihara, T. Soga, M. Nomura et al., "Effect of ER- $\beta$ gene disruption on estrogenic regulation of anxiety in female mice," Physiology and Behavior, vol. 96, no. 2, pp. 300-306, 2009.

[176] A. A. Walf, C. Koonce, K. Manley, and C. A. Frye, "Proestrous compared to diestrous wildtype, but not estrogen receptor beta knockout, mice have better performance in the spontaneous alternation and object recognition tasks and reduced anxietylike behavior in the elevated plus and mirror maze," Behavioural Brain Research, vol. 196, no. 2, pp. 254-260, 2009.

[177] A. A. Walf, C. J. Koonce, and C. A. Frye, "Estradiol or diarylpropionitrile administration to wild type, but not estrogen receptor beta knockout, mice enhances performance in the object recognition and object placement tasks," Neurobiology of Learning and Memory, vol. 89, no. 4, pp. 513-521, 2008.

[178] A. A. Walf, C. J. Koonce, and C. A. Frye, "Estradiol or diarylpropionitrile decrease anxiety-like behavior of wildtype, but not estrogen receptor beta knockout, mice," Behavioral Neuroscience, vol. 122, no. 5, pp. 974-981, 2008. 


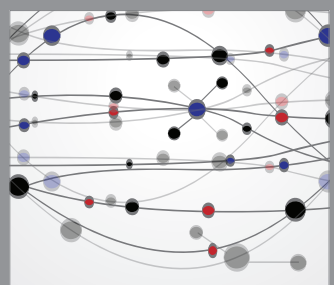

The Scientific World Journal
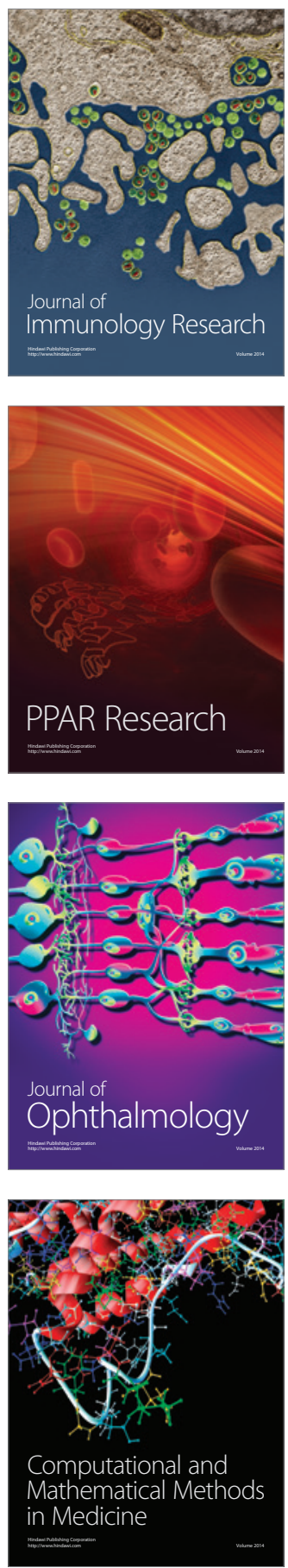

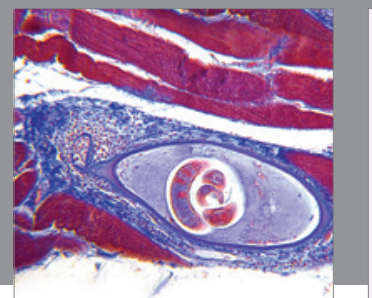

Gastroenterology

Research and Practice
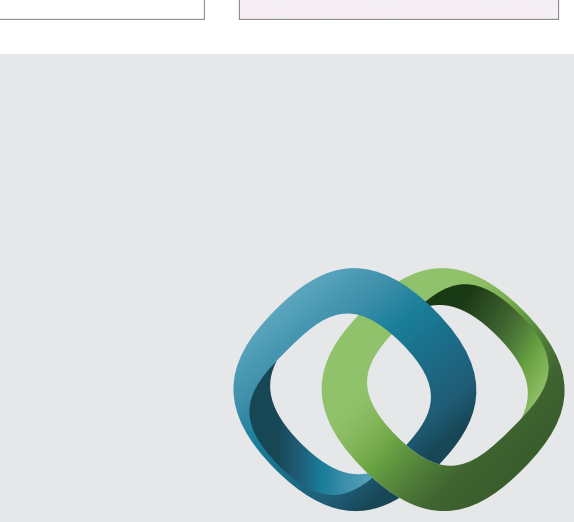

\section{Hindawi}

Submit your manuscripts at

http://www.hindawi.com
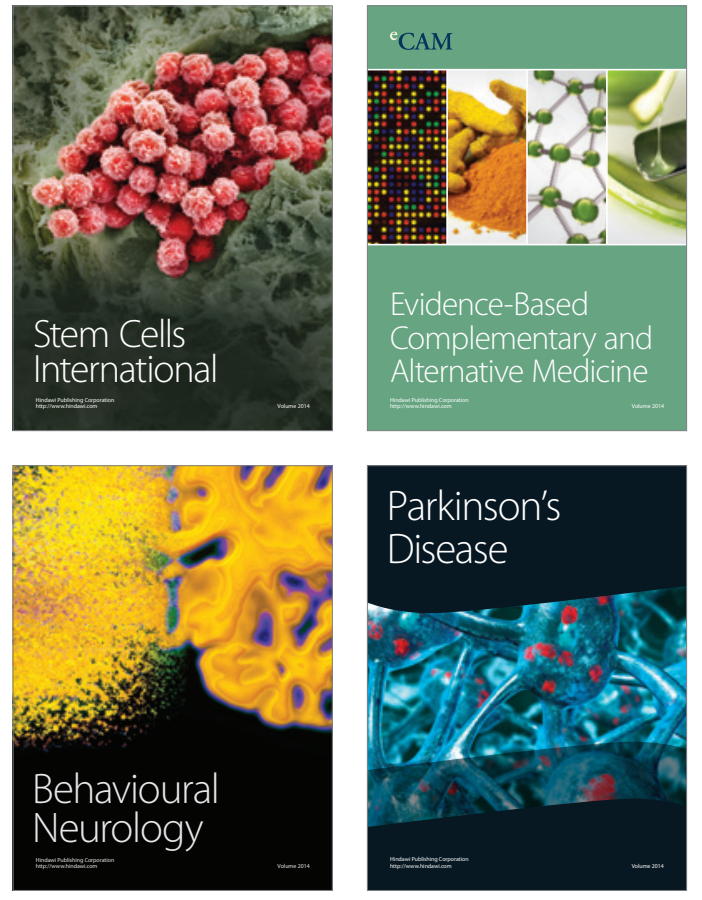
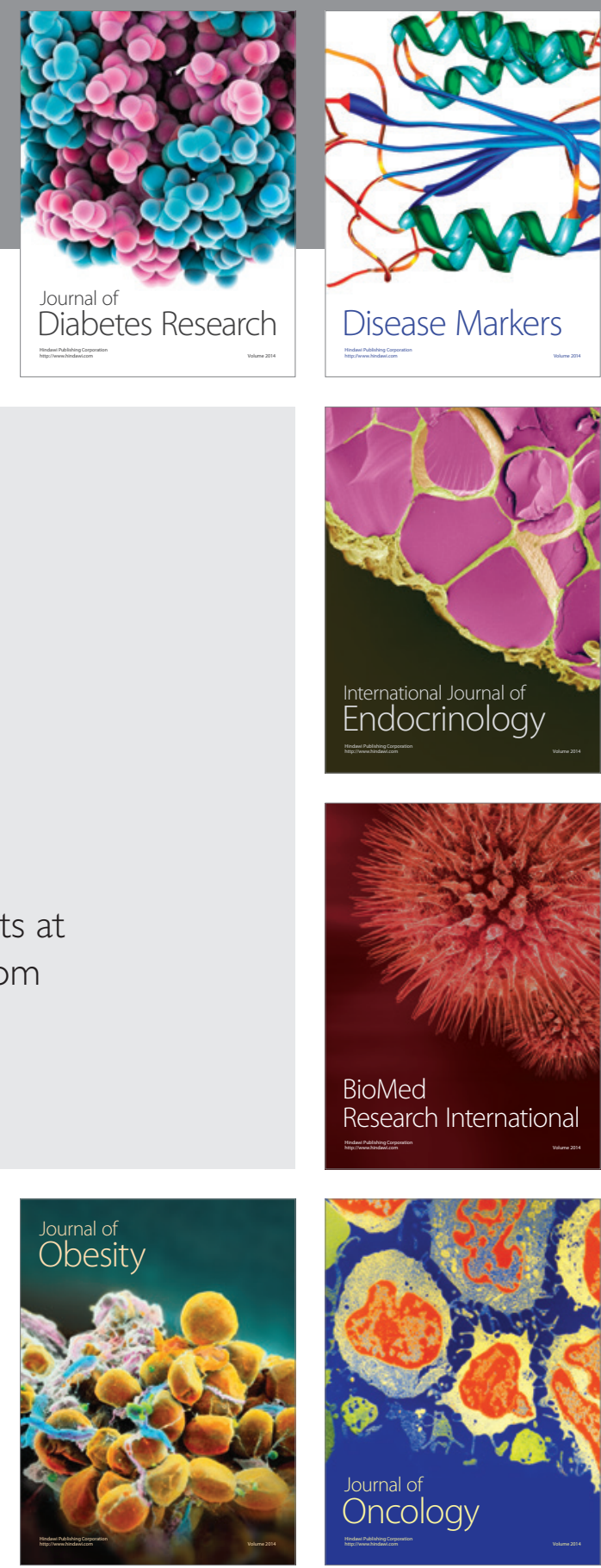

Disease Markers
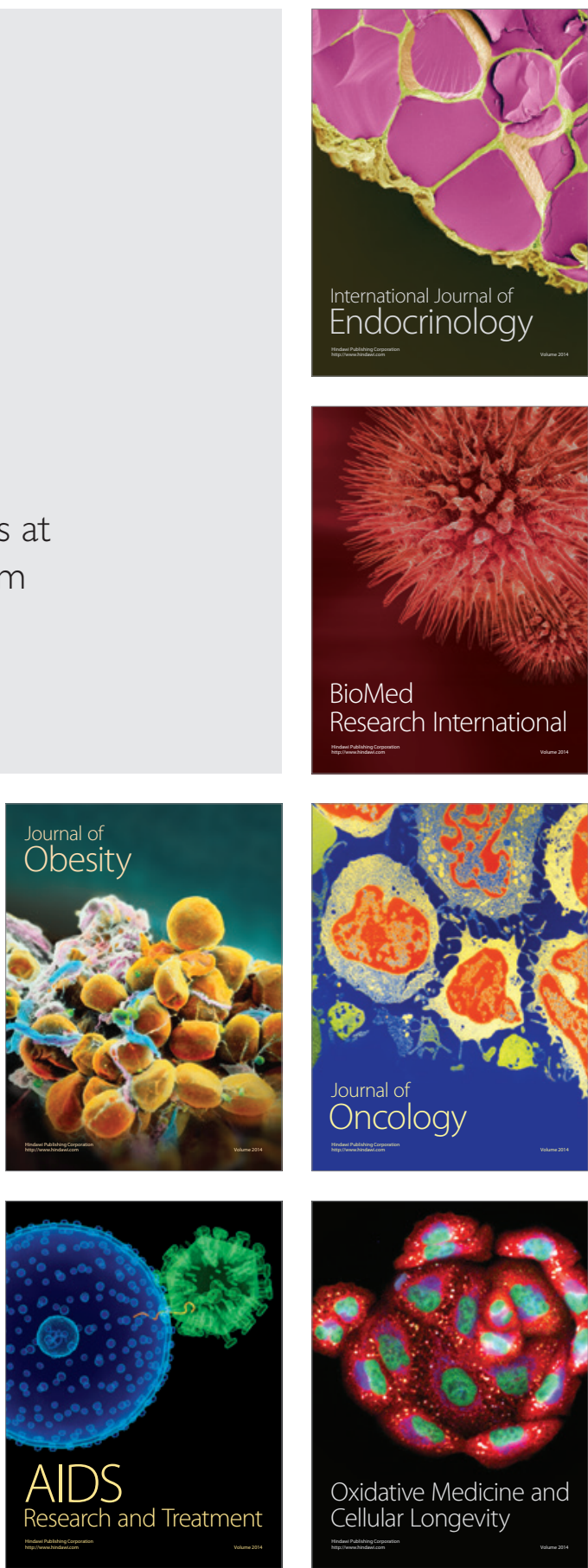